OPEN ACCESS

Edited by:

Rameshwar K. Sharma, Salus University, United States

Reviewed by: Pere Garriga, Universitat Politecnica de Catalunya, Spain

Martin Heine, Leibniz Institute for Neurobiology,

Germany

*Correspondence:

Marcus Niebert mnieber@gwdg.de

Received: 20 June 2017 Accepted: 06 September 2017 Published: 21 September 2017

Citation:

Niebert S, van Belle GJ, Vogelgesang S, Manzke T and Niebert M (2017) The Serotonin Receptor Subtype 5b Specifically Interacts with Serotonin Receptor

Subtype 1A.

Front. Mol. Neurosci. 10:299. doi: 10.3389/fnmol.2017.00299

\section{The Serotonin Receptor Subtype 5b Specifically Interacts with Serotonin Receptor Subtype 1A}

\author{
Sabine Niebert ${ }^{1}$, Gijsbert J. van Belle ${ }^{2}$, Steffen Vogelgesang ${ }^{3,4}$, Till Manzke $\mathrm{k}^{3,4}$ \\ and Marcus Niebert ${ }^{3,4 *}$
}

${ }^{1}$ Department of Maxillofacial Surgery, University Medical Center, Göttingen, Germany, ${ }^{2}$ Institute of Cardiovascular Physiology, University Medical Center, Göttingen, Germany, ${ }^{3}$ Institute of Neuro- and Sensory Physiology, University Medical Center, Göttingen, Germany, ${ }^{4}$ Center Nanoscale Microscopy and Molecular Physiology of the Brain (CNMPB), University Medical Center, Göttingen, Germany

Previously, we described the dysregulation of serotonin (5-HT) receptor subtype $5 b$ $\left(5-h t_{5 b}\right)$ in a mouse model of Rett syndrome $(R T T)$. $5-h t_{5 b}$ has not been extensively studied, so we set out to characterize it in more detail. Unlike common cell surface receptors, 5-ht $t_{5 b}$ displays no membrane expression, while receptor clusters are located in endosomes. This unusual subcellular localization is at least in part controlled by glycosylation of the $\mathrm{N}$-terminus, with $5-\mathrm{ht}_{5 \mathrm{~b}}$ possessing fewer glycosylation sites than related receptors. We analyzed whether the localization to endosomes has any functional relevance and found that 5 -ht $t_{5 b}$ receptors can specifically interact with $5-\mathrm{HT}_{1 \mathrm{~A}}$ receptors and retain them in endosomal compartments. This interaction reduces $5-\mathrm{HT}_{1 \mathrm{~A}}$ surface expression and is mediated by interactions between the fourth and fifth transmembrane domain (TMD). This possibly represents a mechanism by which 5 -ht $t_{5 b}$ receptors regulate the activity of other $5-\mathrm{HT}$ receptor.

\section{Keywords: 5-ht5b receptor, 5-HT1A receptor, Rett syndrome, signaling, cAMP}

\section{INTRODUCTION}

G-protein coupled receptors (GPCRs) make up $2 \%$ of all cellular proteins and constitute one of the most important pharmaceutical drug targets. With all their diversity, GPCRs share some defining features, e.g., they are composed of seven trans-membrane domains (TMD) with three extracellular and four intracellular loops, and many receptors need to form homo- or heterodimers to become functional active (Gurevich and Gurevich, 2008; Schwenk et al., 2010; Pellissier et al., 2011). The receptors relate extracellular signals by activating G-proteins acting on either one of the main effectors calcium ( $G_{q}$ via Phospholipase $C$ ) or cyclic adenosine monophosphate (cAMP). cAMP can be up- or down-regulated via stimulatory $\left(G_{s}\right)$ or inhibitory $\left(G_{i} / G_{0}\right)$ G-proteins who activate or inhibit the adenylate cyclase, respectively. Increases in cAMP may directly activate cyclic nucleotide gated (CNG) ion channels (Kaupp and Seifert, 2002) or protein kinase A (PKA; Meinkoth et al., 1993). Intracellular sensors for cAMP like exchange protein activated by cAMP (EPAC; Bos, 2006) or popeye domain-containing proteins (Popdc, Simrick et al., 2013) function through small GTPases.

Serotonin (5-HT) is a widespread neurotransmitter in the nervous systems, with numerous functions in sensory-motor, autonomic and behavioral systems (Azmitia, 2001). It is also a hormone and paracrine factor in non-neural tissues (Matsuda et al., 2004; Slominski et al., 2005). In

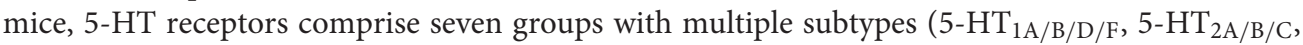
$5-\mathrm{HT}_{4}, 5-\mathrm{ht}_{5 \mathrm{a} / \mathrm{b}}, 5-\mathrm{HT}_{6}$ and $5-\mathrm{HT}_{7}$; Hoyer et al., 2002) for a total of 12 GPCRs, while $5-\mathrm{HT}_{3 \mathrm{~A} / \mathrm{B}}$ 
acts as an ion channel. In humans, four additional 5-HT receptors exist that do not have a known ortholog in mice: $5-\mathrm{HT}_{1 \mathrm{E}}$ is

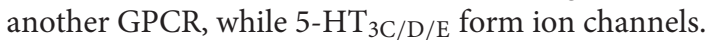

While many 5-HT receptors have been extensively studied (Niebert et al., 2011; Pellissier et al., 2011; Renner et al., 2012), our knowledge of 5-ht 5 receptors is rather limited. Rodents have been shown to possess two functional $5-\mathrm{ht}_{5}$ receptor subtypes, 5-ht 5 a (Plassat et al., 1992) and 5-ht 5 b (Matthes et al., 1993), with their expression being restricted to the brain (Rees et al., 1994). The existence of both receptors was confirmed for humans (Rees et al., 1994; Grailhe et al., 2001; Nelson, 2004), which possess a functional gene for 5 -ht $\mathrm{h}_{5 \mathrm{a}}$, while the coding sequence of the $5-\mathrm{ht}_{5 \mathrm{~b}}$ subtype is interrupted by several stop codons and insertional mutations, making the gene apparently nonfunctional.

$5-\mathrm{ht}_{5 \mathrm{~b}}$ is expressed in many regions throughout the murine brain like bulbus olfactorius, hippocampus, or cerebellum at low levels. However, 5-ht 5 b was found to be upregulated under the control of ATF-7 in mice undergoing social stress (Maekawa et al., 2010). Also, 5-ht 5 b dysregulation was described in mouse models of Rett syndrome (RTT), a severe neurodevelopmental disorder caused by mutations in the transcription factor MeCP2. We found 5-ht $\mathrm{t}_{5 \mathrm{~b}}$ to be developmentally regulated in the brainstem of $M e c p 2^{-/ y}$ mice, where it showed 75-fold upregulation (Vogelgesang et al., 2017), while 5-ht 5 b was also increased in astrocytes of $M e c p 2^{308 / y}$ mice (Delépine et al., 2015). We showed that a full length as well as a truncated protein of $5-\mathrm{ht}_{5 \mathrm{~b}}$ can be detected by Western blot in murine brain lysates (Vogelgesang et al., 2017). Truncation of receptors has been described many times, but previously identified truncated GPCRs were predominantly retained in the endoplasmic reticulum (ER; Karpa et al., 2000; Leung et al., 2007; Gonzalez et al., 2011).

5-ht 5 b's massive dysregulation in a disease model for RTT prompted us to more closely investigate the reasons for and the physiological significance of its subcellular localization.

\section{MATERIALS AND METHODS}

\section{Ethical Statement}

The experimental procedures were performed in accordance with European Community (EU Directive 2010/63/EU for animal experiments) and National Institutes of Health guidelines for the care and use of laboratory animals. The study was approved by the Georg-August-University, Göttingen and the approval ID T12/18 was assigned to this work.

\section{Animals}

C57BL/6J mice were kept in a temperature- and humiditycontrolled $12 \mathrm{~h}$ light-dark cycle and had free access to water and standardized pellet food. The Mecp2 knockout mouse (Mecp2 $2^{-/ y}$ ), strain B6.129P2(C)-Mecp2 ${ }^{\text {tm1-1Bird }}$ (Guy et al., 2001) obtained from The Jackson Laboratory (Bar Harbor, ME, USA) was maintained on a C57BL/6J background. For this work we used wild-type and hemizygous Mecp $2^{+/-}$females.

\section{Cell Culture, Transfection and Plasmids}

Murine neuroblastoma cell line N1E-115 was obtained from the American Type Culture collection (ATCC). Cells were grown in Dulbecco's modified Eagle's medium (DMEM) containing 10\% fetal calf serum (FCS) and $1 \%$ penicillin/streptomycin at $37^{\circ} \mathrm{C}$ under $5 \% \mathrm{CO}_{2}$.

For transient transfection, cells were seeded in cell culture dishes and transfected with indicated plasmids using Lipofectamine2000 Reagent (Invitrogen) according to the manufacturer's instruction.

Primary neurons were obtained from dissociated hippocampi as detailed in Revelo et al. (2014). In brief, hippocampi were extracted from 1 day-old animals. They were incubated for $1 \mathrm{~h}$ in enzyme solution (10 ml DMEM, $2 \mathrm{mg}$ cysteine, $100 \mathrm{mM} \mathrm{CaCl}_{2}$, $50 \mathrm{mM}$ EDTA and $25 \mathrm{U}$ papain, equilibrated with carbogen for $10 \mathrm{~min}$, and sterile filtered). Before mechanical dissociation, cells were washed thoroughly with HBSS (Invitrogen, Waltham, MA, USA) and were incubated for $15 \mathrm{~min}$ in inactivating solution $(2 \mathrm{mg}$ albumin and $2 \mathrm{mg}$ trypsin inhibitor in $10 \mathrm{ml}$ FCS-containing DMEM medium). Sterilized coverslips were coated overnight with $1 \mathrm{mg} / \mathrm{ml}$ poly-L-lysine and were incubated with plating medium (MEM supplemented with 10\% horse serum, $3.3 \mathrm{mM}$ glucose and $2 \mathrm{mM}$ glutamine). Neurons were plated at a concentration of $\sim 30,000 / \mathrm{cm}^{2}$ and were left to adhere for 1-4 h. After adhesion, the medium was changed to Neurobasal-A medium (Gibco, Life Technologies, Carlsbad, CA, USA) containing 1:50 B27 supplement (Gibco) and 1:100 GlutaMAX (Gibco). Neurons were kept in culture at $37^{\circ} \mathrm{C}$ and $5 \% \mathrm{CO}_{2}$.

Expression constructs for 5- $\mathrm{HT}$ receptors $5-\mathrm{HT}_{1 \mathrm{~A}}$ and $5-\mathrm{HT}_{7}$ with either immuno- (HA/myc) or fluorescent tags have been described previously (Renner et al., 2012), while 5-HT receptors $5-\mathrm{HT}_{2 \mathrm{C}}, 5-\mathrm{HT}_{4}, 5-\mathrm{ht}_{5 \mathrm{a}}, 5-\mathrm{ht}_{5 \mathrm{~b}}$ and $5-\mathrm{HT}_{6}$ were generated from murine corresponding deoxyribonucleic acid (cDNA). Brain tissue was explanted and used for total ribonucleic acid (RNA) isolation with the OLS RNA kit (OLS, Germany) according to the manufacturer's instructions. The total RNA was used in one-step RT-PCR (Invitrogen) and resulting PCR fragment was cloned into pTarget expression vector (Promega). Primer sequences are given in Table 1. To obtain a C-terminal fluorophore fusion construct, the receptor and the fluorophores CFP, GFP, YFP or $\mathrm{mRFP} / \mathrm{mCherry}$ were amplified individually, and fusion PCR was used to combine the cDNAs. The resulting PCR fragment was cloned into the pTarget expression vector (Promega). To test the hypothesis of a truncated $5-\mathrm{ht}_{5 \mathrm{~b}}$ receptor, we amplified the unlabeled and the mCherry fusion construct and cloned the fragments into pTarget. The truncated $5-\mathrm{ht}_{5 \mathrm{~b}}$ comprises the nucleotides from position 520 to 1113 . As a control, a truncated $5-\mathrm{HT}_{7}$ was prepared in the same way. The truncated $5-\mathrm{HT}_{7}$ comprises the nucleotides from position 520 to 1347 . Correct sequences of all constructs were determined by sequencing.

\section{Generation of Glycosylation-Deficient 5- $\mathrm{HT}_{1 \mathrm{~A}}$ Constructs}

Wild type $5-\mathrm{HT}_{1 \mathrm{~A}}$ can be glycosylated at four positions (N10, N11, N24, N30) at the N-terminus. Following the glycosylation experiments on 5-ht $5 \mathrm{a}$, we used site-directed mutagenesis 
TABLE 1 | List of primers used in this study for cloning.

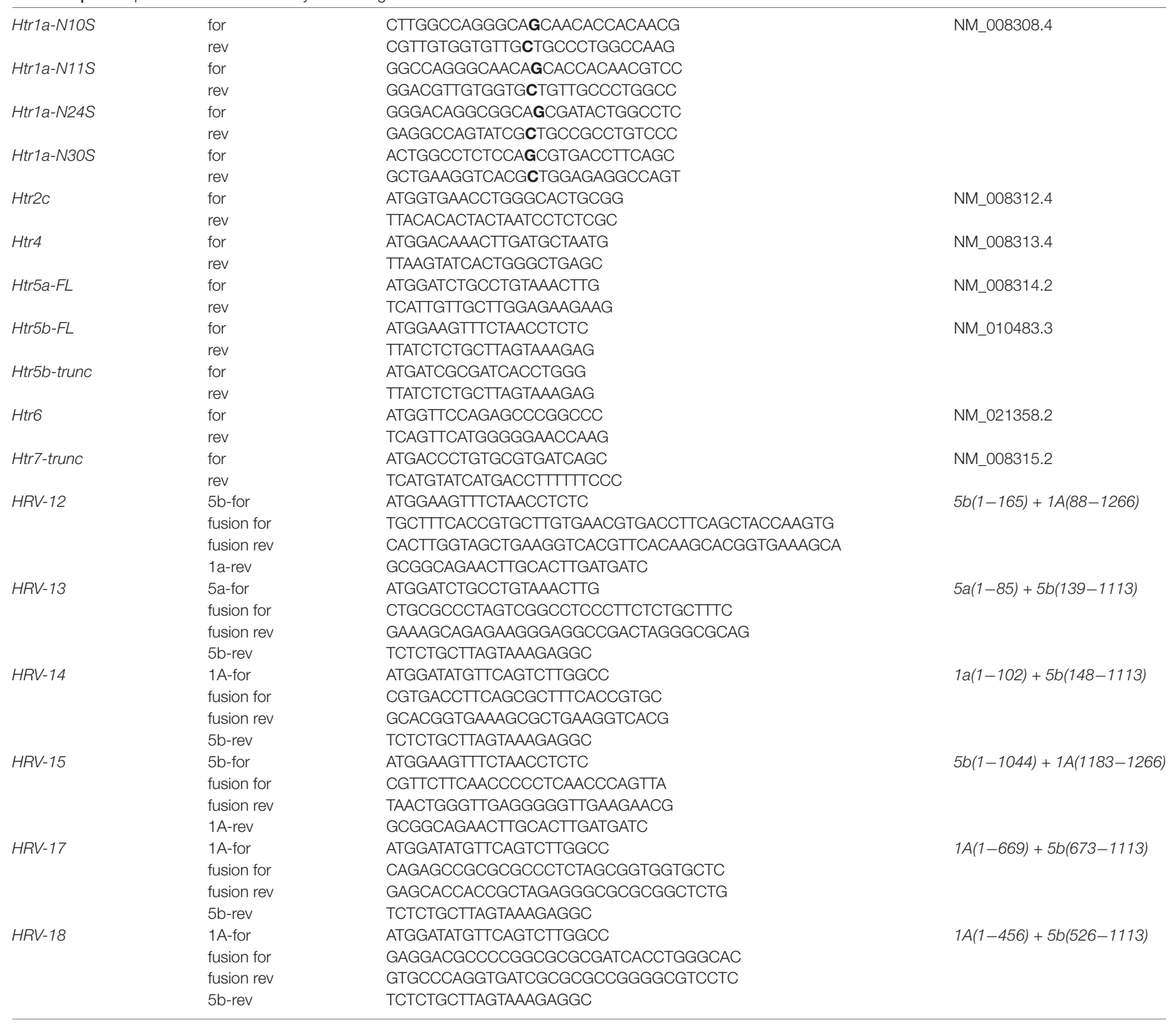

Accession numbers are given for the murine gene used to generate the primers.

(Quickchange II, Agilent) to change each individual Asparagine to Serine (Dutton et al., 2008). To generate clones with multiple exchanges, we performed subsequent rounds of mutagenesis. Primers used for mutagenesis are given in Table $\mathbf{1}$ and correct sequences of all constructs were determined by sequencing.

\section{Generation of Hybrid Receptors}

The modular structure of the GPCRs facilitates easy exchange of domains between receptors, which has previously been used successfully to generate versions with completely new characteristics (Conklin et al., 2008). 5-HT receptors are composed of seven TMD, which are connected by three extra(ECL) and three intra-cellular loops (ICL). The extra-cellular $\mathrm{N}$-terminus takes part in ligand attraction, while the intracellular C-terminus often, but not always features a PDZ-like domain and takes part in membrane anchoring or protein binding. The problem with this approach is the difficulty to predict domain boundaries, as incorrectly chosen domains may prevent correct folding and therefore render the new hybrid receptor functionless. As we employed this strategy multiple times, we took care to validate the correct function of the new hybrid receptors. Our first quality check was their production of a distinct staining, be it intracellular or membrane bound. All variants that showed a diffuse staining were assumed to be incorrectly folded and were not used for further studies. As long as the receptor showed at least some membrane localization, we also tested the hybrid receptor for its reaction to its natural ligand 5-HT.

DNA sequences coding for TMDs were identified using TMHMM server 2.0 (Krogh et al., 2001). Hybrid receptors were 
generated using fusion PCR. Therefore, the DNA sequences to be fused were separately amplified by PCR using specific primers, introducing a small overlapping DNA region. After purification of both PCR products by gel extraction, $10 \mathrm{ng}$ of each DNA was used as template for a subsequent fusion PCR using primers specific for the full-length hybrid open reading frame. The primers used for generation of different variants of Htrla$H t r 5 b$ hybrid receptor variants are given in Table $\mathbf{1}$.

\section{RT-PCR}

The total RNA of homogenized tissue from specific brain regions was isolated using the Trizol $^{\circledR}$ method according to manufacturer's instructions (GibcoBRL) and its concentration was determined using the nanodrop ND-1000 spectrophotometer followed by its quality and integrity measurement by electrophoresis on RNA 6000 LabChip ${ }^{\circledR}$ kit (Agilent 2100 Bioanalyzer). The RNA was transcribed into the cDNA using the iScript cDNA Synthesis Kit (BioRad). The primer pairs used for RT-PCR are the same used previously for quantitative RT-PCR (Vogelgesang et al., 2017).

\section{Immuno-Staining Procedures}

To obtain tissue, mice (P40) were deeply anesthetized with isoflurane (1-Chloro-2,2,2-trifluoroethyl-difluoro-methylether, Abbott, Germany) until they were unresponsive to pain stimuli. A thoracotomy was performed and animals were transcardially perfused with $50 \mathrm{ml}$ of $0.9 \% \mathrm{NaCl}$ followed by $200 \mathrm{ml}$ of $4 \%$ phosphate-buffered formaldehyde $(10 \mathrm{ml} / \mathrm{min})$. The brain was removed and post-fixed for $4 \mathrm{~h}$ with the same fixative at $4^{\circ} \mathrm{C}$. Whole brains were stored in $1 \%$ formaldehyde in PBS at $4^{\circ} \mathrm{C}$. Before sectioning, brains were equilibrated in HEPES buffer (7, $5 \mathrm{~g} \mathrm{NaCl}, 0.3 \mathrm{~g} \mathrm{KCl}, 0.06 \mathrm{~g} \mathrm{KH}_{2} \mathrm{PO}_{4}, 0.13 \mathrm{~g} \mathrm{Na}_{2} \mathrm{HPO}_{4}, 2 \mathrm{~g}$ Glucose, $2.4 \mathrm{ml} 10 \mathrm{mM}$ HEPES, $0.1 \mathrm{~g} \mathrm{MgCl}_{2}, 0.05 \mathrm{~g} \mathrm{MgSO}_{4}$, $0.165 \mathrm{~g} \mathrm{CaCl}_{2}, \mathrm{pH} 7.4$ ) for $48 \mathrm{~h}$, cryoprotected in $15 \%$ sucrose in PBS for $24 \mathrm{~h}$ followed by equilibration in $30 \%$ sucrose in PBS for $24 \mathrm{~h}$ at $4^{\circ} \mathrm{C}$, and then frozen at $-80^{\circ} \mathrm{C}$. Series of $30 \mu \mathrm{m}$ thick brain sections were cut using a freezing microtome (Frigocut, Reichert-Jung, Germany). Sections were stored in HEPES buffer. All buffers were supplemented with a small amount of sodium azide.

The polyclonal antibody against the murine $5-\mathrm{ht}_{5 \mathrm{~b}}$ receptor was generated by immunizing rabbits with a $15 \mathrm{mer}$ peptide representing the C-terminus of the receptor (NP_034613.1; NH2-KNYNNAFKSLFTKQR-COOH). Peptides were coupled to keyhole limpet hemocyanin (KLH) and $300 \mu \mathrm{g}$ KLH-coupled peptide in Hunter's adjuvant (TiterMax Gold, Sigma) was administered five times (28-days-intervall). Antibodies were purified on an antigen-coupled CNBr-activated Sepharose ${ }^{\circledR} 4 \mathrm{~B}$ column. The eluate was dialyzed against two changes of 51 PBS for $24 \mathrm{~h}$ at $4^{\circ} \mathrm{C}$, and finally concentrated to at least $1 \mu \mathrm{g} \mathrm{IgG/ \mu l}$.

Primary antibodies were diluted 1:100 in blocking buffer (PBS, $0.1 \%$ Triton-X100, 1\% Tryptone/Peptone) and incubated for $60 \mathrm{~min}$ at RT. After washing in washing buffer (PBS, $0.05 \%$ Tween 20, 0.3\% Triton X100), sections were incubated for $1 \mathrm{~h}$ at RT in the dark with anti-rabbit atto647-conjugated secondary antibodies (Sigma-Aldrich, Cat. No. 40839) diluted 1:400 in blocking buffer. Sections were mounted onto microscope-slides and cover-slipped with Mowiol.

To analyze interaction of $\mathrm{HA}-5-\mathrm{HT}_{1 \mathrm{~A}}$ and $5-\mathrm{ht}_{5 \mathrm{~b}}$ mCherry in N1E-115 neuroblastoma cells, double-transfected live cells were first stained at low temperatures with rabbit-anti-HA-tag primary antibodies for $5 \mathrm{~min}$ and anti-rabbit atto647-conjugated secondary antibodies for $5 \mathrm{~min}$ to avoid internalization. Cells were then fixed and permeabilized before they were stained again with mouse anti-HA-tag primary antibodies and anti-mouse atto488-conjugated secondary antibodies.

\section{Counterstaining of Intracellular Compartments}

The plasmids to fluorescently label the cell membrane (pYFPMem), the ER (pYFP-ER), mitochondria (pYFP-mito) and peroxisomes (pEGFP-Pex) were obtained from Clontech. The plasmid to label the endosomes (GFP-Rab5; Addgene plasmid \# 31733) was a gift from Richard Pagano (Choudhury et al., 2002). Lysosomes were counterstained with Lamp1-GFP.

Co-localization was observed using Zeiss LSM 510 Meta system. Quantitative analysis of co-localization was carried out by calculating Pearson's correlation coefficients using LSM 510 software.

\section{Confocal Laser-Scanning Microscopy}

Distribution of recombinant receptors, organelle markers and immuno-fluorescent staining was analyzed by microscopy using a confocal laser scanning microscope LSM 510 Meta (Carl Zeiss, Jena, Germany) equipped with a $63 \times$ plan-apochromatic phasecontrast water-immersion objective, NA 1.4. Fluorophores were excited either with light at $458 \mathrm{~nm}, 488 \mathrm{~nm}$ or $514 \mathrm{~nm}$ from an Argon laser, at $543 \mathrm{~nm}$ from a HeNe laser or at $633 \mathrm{~nm}$ from a second HeNe laser. Emission of the fluorophores was recorded using the Meta detector. Analysis, e.g., intensity measurements, were performed by importing the images into Image (Schneider et al., 2012). For plate assembly, images were digitally adjusted for brightness and contrast if necessary.

\section{Förster Resonance Energy Transfer (FRET) Acceptor Photobleaching}

Cells were transfected with equimolar amounts of $5-\mathrm{HT}_{1 \mathrm{~A}}-\mathrm{GFP}$ and 5-ht $5 \mathrm{~b}$-mCherry or with GFP-rab5 and mRFP-rab5 (a gift from Ari Helenius (Addgene plasmid \# 14437, Vonderheit and Helenius, 2005) or with single plasmids for negative control and fixed using $2 \%$ paraformaldehyde for $20 \mathrm{~min}$ prior to imaging. After collecting three images in both the GFP and the mRFP channels, the mRFP in the regions of interests (ROIs) were photobleached by scanning 50 times at high laser power. After photobleaching, again three images of both channels were taken. The obtained images were averaged to calculate the $\mathrm{GFP}_{\text {before}}, \mathrm{GFP}_{\text {after, }} \mathrm{mRFP}_{\text {before }}$ and $\mathrm{mRFP}_{\mathrm{after}}$ values. The apparent Förster Resonance Energy Transfer (FRET) efficiency was calculated using the following formula: Apparent FRET efficiency $=\left(\left(\mathrm{GFP}_{\text {after }}-\mathrm{GFP}_{\text {before }}\right) \times \mathrm{mRFP}_{\text {before }}\right) \times\left(\left(\mathrm{GFP}_{\text {after }} \times\right.\right.$ $\left.\left.\mathrm{mRFP}_{\text {before }}\right)-\left(\mathrm{GFP}_{\text {before }} \times \mathrm{mRFP}_{\text {after }}\right)\right)^{-1}$ (van Royen et al., 2009). Image analysis was performed in ImageJ (Schneider et al., 2012). 


\section{Fluorescence Activated Cell Sorting (FACS) Analysis}

To determine to what extent $5-\mathrm{ht}_{5 \mathrm{~b}}$ expression affects translocation of 5- $\mathrm{HT}_{1 \mathrm{~A}}$ to intracellular organelles, we performed QD-mediated fluorescence activated cell sorting (FACS) analysis to measure the amount of surface expression of HA-5-HT $\mathrm{H}_{1 \mathrm{~A}}$. Cells expressing $\mathrm{HA}-5-\mathrm{HT}_{1 \mathrm{~A}}$ and $5-\mathrm{ht}_{5 \mathrm{~b}}$ at equimolar ratios were compared to cells expressing HA-5-HT $1 \mathrm{~A}$ transfected with the same amount of DNA together with an equimolar amount of unspecific cDNA to compensate for transcriptional effects. Cells were fixed in $2 \%$ paraformaldehyde/PBS for $15 \mathrm{~min}$ and labeled with excess of primary antibody against rabbit-anti-HA-tag (Santa Cruz, sc-805) and with a secondary antibody coupled to quantum dots (655 nm, Invitrogen). Avoiding cell permeabilization as well as the bulk of the QDs ensured that no intracellular proteins were labeled. Samples were run on a modified LSR II instrument from Becton and Dickinson using $405 \mathrm{~nm}$ excitation and a 660/40 nm emission filter.

\section{Quantification of cAMP Signaling}

The ability of 5-HT to modulate cAMP levels in cells under pharmacological treatment was assessed with the cAMP-Glo assay (Promega) according to the manufacturer's instructions. cAMP amounts were determined by fitting the results from triplicate experiments to the standard curve. The phosphodiesterase inhibitor IBMX $(50 \mathrm{mM})$ was present during this treatment.

\section{Statistical Analysis}

Statistical significance of the data was tested by one-wayANOVA with Bonferroni's post-test for multiple comparisons using GraphPad Prism 6 (GraphPad Software Inc., La Jolla, CA, USA) on a Microsoft Windows PC. A p-value of less than 0.05 was considered significant. Data are presented as mean \pm standard error of the mean (SEM).

\section{RESULTS}

\section{The 5-ht fb $_{\mathrm{b}}$ Receptor Shows an Unusual Intracellular Localization}

When expressed in N1E-115 cells, most 5-HT receptors produced a clear membrane-localized signal with minor staining of the Golgi apparatus due to trafficking (Figure 1A). With $5-\mathrm{HT}_{4}$ and $5-\mathrm{HT}_{6}$, membrane staining was strong, however a moderate amount of punctate clusters were visible in transfected cells. Only 5-ht $5 \mathrm{a}$ and $5-\mathrm{ht}_{5 \mathrm{~b}}$ showed a strong, punctate intracellular localization with little $\left(5-\mathrm{ht}_{5 \mathrm{a}}\right)$ or no $\left(5-\mathrm{ht}_{5 \mathrm{~b}}\right)$ membrane staining at all. We have previously described that $5-\mathrm{ht}_{5 \mathrm{~b}}$ is retained in intracellular organelles with the most significant co-localization found with endosomes and fluorescence immunohistochemistry on mouse brainstem sections detected 5-ht 5 b positive cells (Figure 1B01). High magnification images of this area revealed a clustered sub-cellular localization for $5-\mathrm{ht}_{5 \mathrm{~b}}$ in these cells (Figures 1B02,03). 5-ht $5 \mathrm{~b}$ shows massive dysregulation in a mouse model of RTT
(Vogelgesang et al., 2017). To follow up on the previously published results, we tested the sub-cellular localization of 5-ht 5 b in primary hippocampal neurons (Figure 1C) and could verify the results from N1E-115 cells with the highest co-localization of $5-\mathrm{ht}_{5 \mathrm{~b}}$ with endosomal marker rab5 (0.867 \pm 0.016$)$, while markers for membrane $(0.035 \pm 0.007)$, mitochondria $(0.538 \pm 0.06)$, ER $(0.273 \pm 0.17)$ and lysosome $(0.471 \pm 0.11)$ showed little overlap.

\section{$\mathrm{N}$-Terminal Glycosylation of $\mathbf{5}-\mathrm{ht}_{5}$ Receptors Controls Intracellular Localization}

Based on literature and the truncation experiments, the most likely mechanism responsible for sorting proteins between membrane and intracellular organelles other than distinct localization signals is glycosylation of the N-terminus (Vagin et al., 2009; Guangyu, 2015). An influence of glycosylation on the trafficking of 5-ht 5 a was also shown previously (Dutton et al., 2008), with two glycosylation sites identified at N6 and N21 (Figure 2B). Incidentally, the intracellular clusters of $5-\mathrm{ht}_{5 \mathrm{a}}$ also co-localize strongest with endosomal markers (data not shown). Analyzing the protein sequences of 5-HT receptors, we found that strictly plasma membrane localized $5-\mathrm{HT}_{1 \mathrm{~A}}$ receptor possess four N-terminal glycosylation sites (Figure 2A) at positions $\mathrm{N} 10, \mathrm{~N} 11, \mathrm{~N} 24$ and N30, while 5 -ht $_{5 \mathrm{~b}}$ receptors (Figure 2C) possess only one glycosylation site at position N5. As 5-ht 5 b can be detected in Western blots of murine brain both as a full length as well as a truncated protein (Vogelgesang et al., 2017), we tested if the truncation causes intracellular localization. An artificially truncated $5-\mathrm{HT}_{7 \text {-trunc }}$ produced a similar staining with completely absent membrane localization and fluorescence concentrated in intracellular organelles (Figure 2D). However, 5 - $\mathrm{HT}_{7-\text { trunc }}$ co-localized strongest with the lysosomal marker (data not shown). Thus, the artificial truncation led to a defective receptor that either folds incorrectly or is otherwise marked for degradation and is sent to the lysosome.

In contrast, the number of glycosylation sites corresponds well with the strength of membrane expression with no discernable membrane staining in case of 5 -ht $_{5 b}$ (Figure 2C), weak staining for $5-\mathrm{ht}_{5 \mathrm{a}}$ (Figure $2 \mathrm{~B}$ ) and strong staining for 5- $\mathrm{HT}_{1 \mathrm{~A}}$ (Figure 2A).

Successive removal of glycosylation sites in $5-\mathrm{HT}_{1 \mathrm{~A}}$ by site-directed mutagenesis led to increasing loss of surface expression. While removing one glycosylation site had no visible effect (data not shown), removal of two glycosylation sites produced only weak surface expression and strong endosomal accumulation of the receptor (Figure 2E). Removal of three or more glycosylation sites led to a total loss of surface expression (data not shown). Complete, yet unspecific de-glycosylation of $5-\mathrm{HT}_{1 \mathrm{~A}}$ receptors with $1 \mu \mathrm{M}$ Tunicamycin (Figure $2 \mathrm{~F}$ ) blocked cell surface localization of the receptor indicating a glycosylation dependence of its trafficking.

Hybrid receptor constructs composed of the extracellular $\mathrm{N}$-terminus of $5-\mathrm{HT}_{1 \mathrm{~A}}$ or $5-\mathrm{ht}_{5 \mathrm{a}}$ receptors and the $5-\mathrm{ht}_{5 \mathrm{~b}}$ receptor (Figures $\mathbf{2 H}, \mathbf{I}$ ) reconstitute 5 -ht $_{5 b}$ receptor localization on the cell membrane with staining intensity depending on the strength of the glycosylation signal. In contrast, 

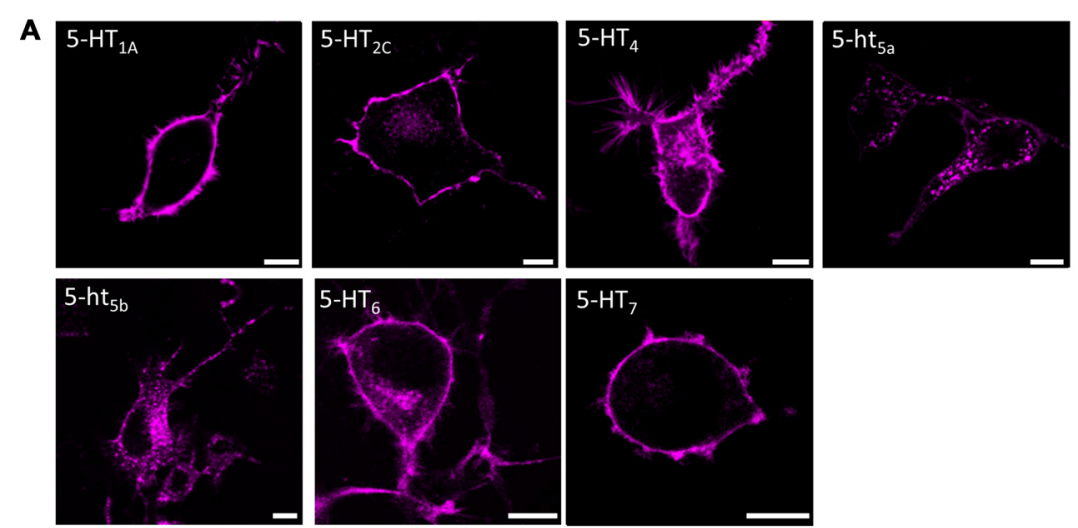

B 01
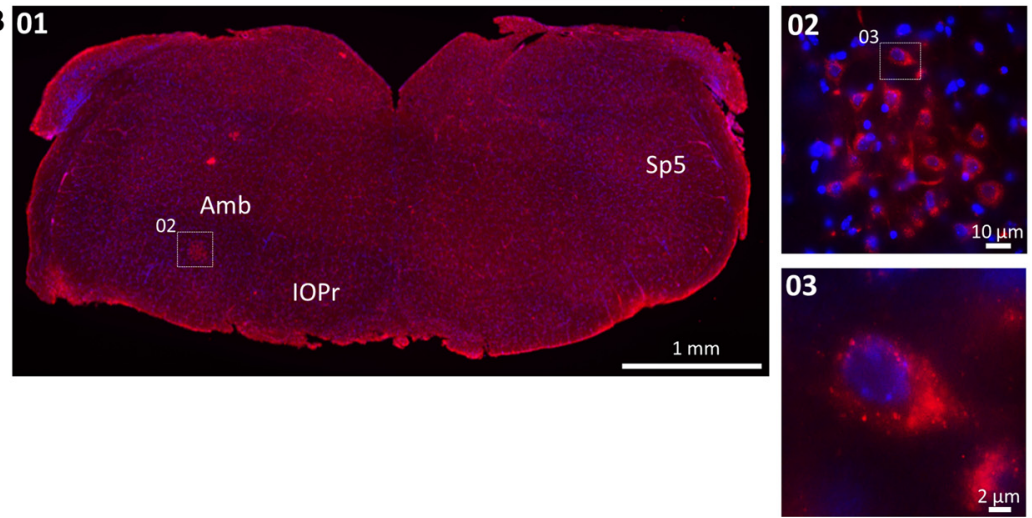
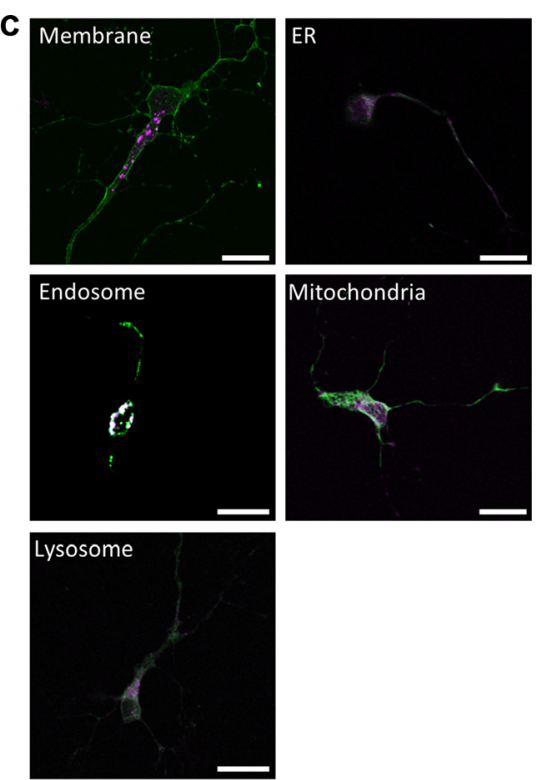

FIGURE 1 | Subcellular localization of serotonin (5-HT) receptors in vitro and in vivo. (A) When expressed recombinantly in N1E-115 cells, 5-HT $1 \mathrm{~A} / 2 \mathrm{C} / 4 / 6 / 7$ produce a clear membrane staining. In contrast, 5-ht $5 a / 5 b$ produce a distinct intracellular staining with weak (5-ht $5 a$ ) or no (5-ht $5 b$ ) membrane staining. Artificially truncating the other 5 - HT receptors (here shown exemplarily for $5-\mathrm{HT}_{7}$ ) produces the same intracellular pattern observed for 5 -ht $5 \mathrm{a} / 5 \mathrm{~b}$. Scale bars represent $10 \mu \mathrm{m}$. (B) The intracellular localization of $5-\mathrm{ht}_{5 \mathrm{~b}}$ is not an artifact of recombinant expression, but can be visualized in vivo. Immunohistological staining of murine brainstem (01) from hemizygous Mecp ${ }^{+/-}$mice against 5-ht 5 b (see "Materials and Methods" Section) reveals upon magnification (02) the same clustered intracellular localization (03) as seen in cells. Scale bars as indicated. Bregma is -6.5. Abbreviations: Amb, Nucleus ambiguus; IOPr, inferior olive, principal nucleus; Sp5, spinal trigeminal tract. (C) Co-localization of 5-HT receptor 5-ht 5 burple) with cellular compartment markers (green) in primary hippocampal neurons. Neurons between DIV 9 to DIV 11 were transfected with fluorescently labeled 5-HT receptor 5-ht 5 b and compartment markers for membrane (GAP-43), endoplasmic reticulum (ER; recognition sequence of calreticulin), mitochondria (recognition sequence of cytochrome C-oxidase), lysosomes (Lamp-1) and endosomes (rab5). The strongest co-localization is with the endosomal marker. Scale bars in all images are $20 \mu \mathrm{m}$.

fusion of the $\mathrm{N}$-terminus of $5-\mathrm{ht}_{5 \mathrm{~b}}$ to $5-\mathrm{HT}_{1 \mathrm{~A}}$ abolishes membrane localization (Figure 2G). As it had already been confirmed for 5-ht 5 a (Dutton et al., 2008), we concluded that $\mathrm{N}$-terminal glycosylation also determines the membrane trafficking of $5-\mathrm{ht}_{5 \mathrm{~b}}$.

\section{5-ht ${ }_{5 b}$ Specifically Interacts with $\mathbf{5 - H T _ { 1 A }}$}

Knowing that many GPCRs (Gurevich and Gurevich, 2008; Schwenk et al., 2010) and some 5-HT receptors in particular (Pellissier et al., 2011; Renner et al., 2012) form homo- or heterodimers, we wanted to know whether co-expression with other 5-HT receptors could lead to a stronger surface expression of $5-h t_{5 b}$.

We co-expressed a representative member of each 5-HT receptor subgroup tagged with mCherry against the same set of 5-HT receptors now tagged with GFP (Figure 3A). However, we excluded $5-\mathrm{HT}_{3} \mathrm{R}$ in this matrix because it is a multimeric ion channel (Uetz et al., 1994; Boyd et al., 2002). Quantification of the correlation coefficients revealed three separate populations (Figure 3B). Here, one population corresponds to the receptor pairs that co-localize to the plasma membrane while the other corresponds to receptor pairs that remain separated between membrane and intracellular organelles. The third population was comprised of the receptor pairs that showed possible interaction. Of this group, the receptor pair of $5-\mathrm{HT}_{1 \mathrm{~A}}$ and $5-\mathrm{ht}_{5 \mathrm{~b}}$ displayed the most unusual behavior, with $5-\mathrm{ht}_{5 \mathrm{~b}}$ not showing enhanced surface expression, but instead retaining $5-\mathrm{HT}_{1 \mathrm{~A}}$ in the endosomal compartments with select specificity (Figure 3A04). This change of $5-\mathrm{HT}_{1 \mathrm{~A}}$ 's sub-cellular localization could also be reproduced in primary neurons (Figure 3C).

After observing the retention of $5-\mathrm{HT}_{1 \mathrm{~A}}$ on intracellular organelles by 5 -ht $t_{5 b}$, we looked for the mechanism. With GPCRs known to form oligomers, direct interaction was an obvious answer, but overloading of the transport pathway was also possible. To differentiate between both mechanisms, we performed a series of experiments while always using equal amounts of transfected DNA. 


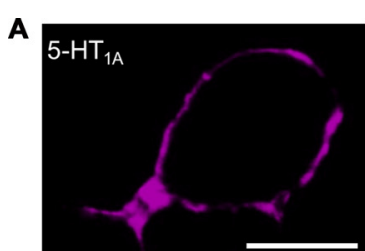

B $5-$ ht $_{5 \mathrm{a}}$

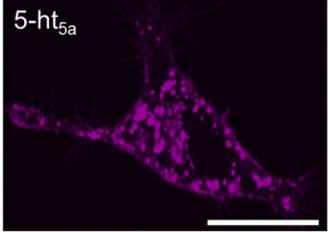

C 5 -ht
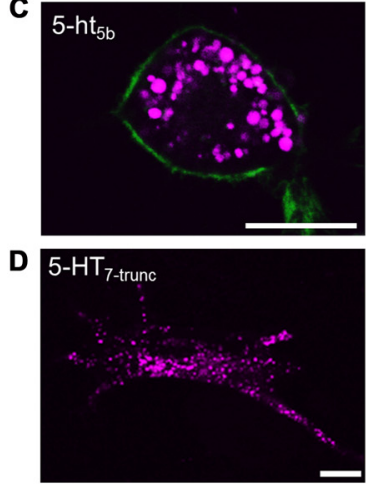

E $5-\mathrm{HT}_{1 \mathrm{~A}}-\mathrm{N} 24 / 30 \mathrm{~S}$

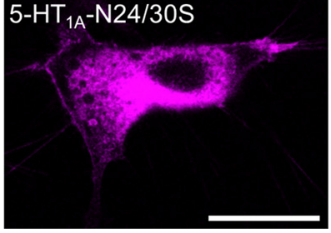

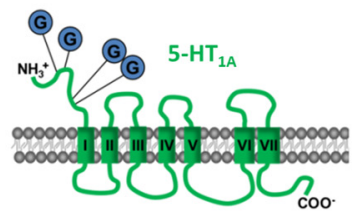
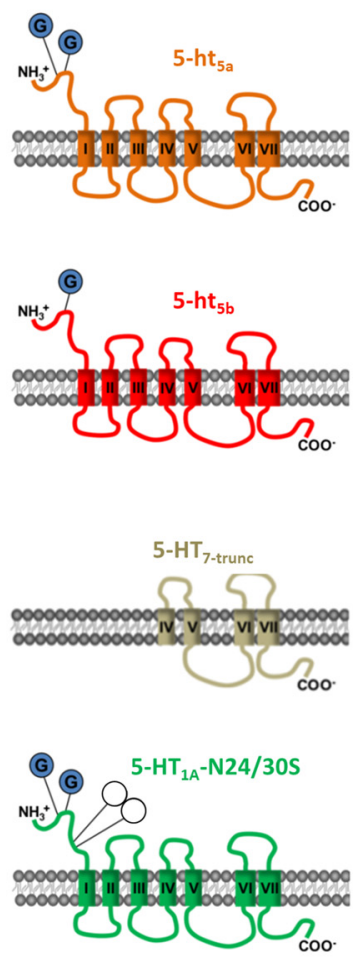
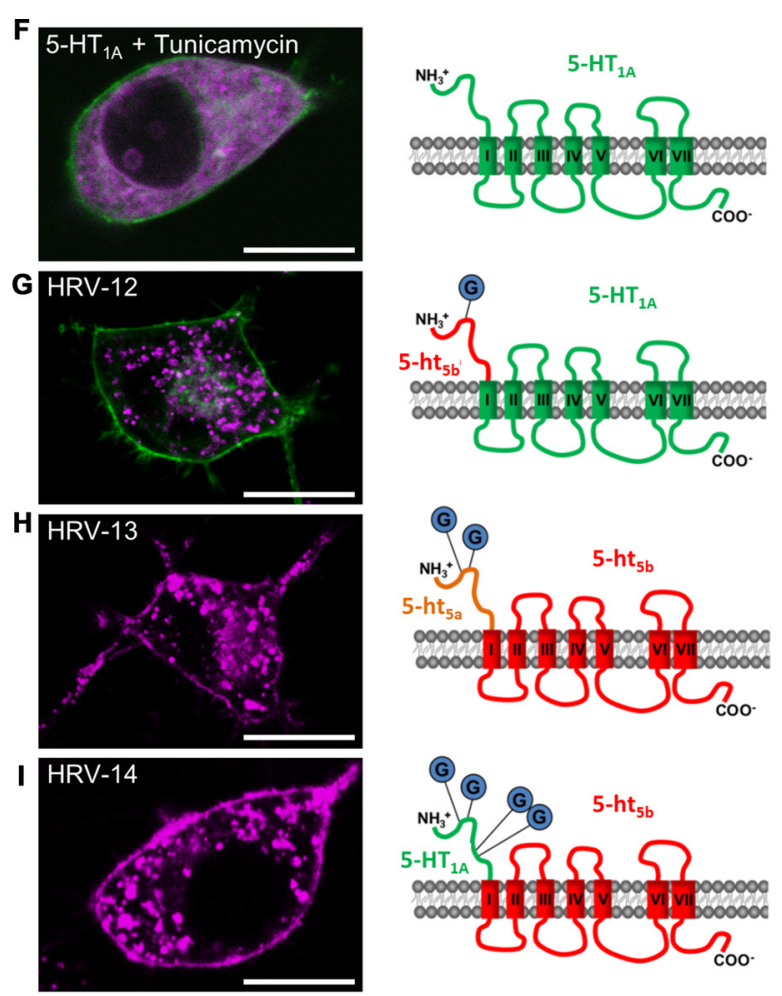

FIGURE 2 | Effect of N-terminal glycosylation on membrane trafficking of 5-HT receptors. For all experiments, N1E-115 cells were transiently transfected with the same amount of receptor corresponding deoxyribonucleic acid (cDNA). All receptor constructs are shown in purple. If the outline of the cell was not easily recognized, a membrane label (GAP-43) was co-transfected (green). (A) 5- $\mathrm{HT}_{1 \mathrm{~A}}$ possesses four glycosylation sites on the N-terminus and displays specific membrane localization. (B) 5-ht 5 a possesses only two glycosylation sites. In comparison to the other 5-HT receptors, 5-ht 5 a shows weak membrane staining, but pronounced staining of endosomal compartments. (C) 5 -ht $_{5 b}$ possesses only one glycosylation site and membrane localization of the receptor is not detectable. (D) Artificially truncated 5-HT receptor 5-HT7 (5-HT7-trunc) comprises the trans-membrane domains (TMDs) IV to VII and shows strong intracellular clustering with no discernable membrane staining. (E) Site-directed mutagenesis of Asparagine (N) to Serine (S) at positions 24 and 30 in 5- $\mathrm{HT}_{1 \mathrm{~A}}-\mathrm{N} 24 / 30 \mathrm{~S}$ removes two of four glycosylation sites and greatly reduces membrane trafficking of the mutated receptor. (F) Tunicamycin blocks the formation of protein $\mathrm{N}$-glycosidic linkages by inhibiting the transfer of $\mathrm{N}$-acetylglycosamine-1-phosphate to dilichol mono-phosphate. Application of Tunicamycin (1 $\mu \mathrm{g} / \mathrm{ml})$ to cells expressing 5 - $\mathrm{HT} \mathrm{T}_{1 \mathrm{~A}}$ removes the receptor from the cell membrane. (G) Replacing the N-terminal domain of 5- $\mathrm{HT}_{1 \mathrm{~A}}$ containing 4 glycosylation sites with the N-terminal domain of 5-ht 5 b with 1 glycosylation site completely abolishes membrane localization of the hybrid receptor and produces a clustered intracellular staining. (H) Replacing the $\mathrm{N}$-terminal domain of 5 -ht 5 b containing 1 glycosylation site with the $\mathrm{N}$-terminal domain of $5-\mathrm{ht}_{5 a}$ with 2 glycosylation sites produces a clustered intracellular staining and produces moderate membrane localization. (I) Replacing the N-terminal domain of 5-ht ${ }_{5 b}$ containing 1 glycosylation site with the $\mathrm{N}$-terminal domain of 5 - $\mathrm{HT}_{1 \mathrm{~A}}$ with 4 glycosylation sites does not prevent intracellular localization, but leads to significant membrane localization of the hybrid receptor. Scale bars in all images are $10 \mu \mathrm{m}$.

An early indicator for interaction was the specificity of interaction. The change of subcellular localization only happens between $5-\mathrm{HT}_{1 \mathrm{~A}}$ and $5-\mathrm{ht}_{5 \mathrm{~b}}$, but not between $5-\mathrm{HT}_{1 \mathrm{~A}}$ and any other receptor or $5-\mathrm{ht}_{5 \mathrm{~b}}$ and any other receptor.

First, we tested direct interaction using acceptorphotobleaching FRET (abFRET) microscopy (Figure 4A) using GFP- and mRFP-labeled constructs (see Materials for details). Apparent FRET efficiency $\left(\mathrm{F}_{\mathrm{app}}\right)$ of the two 5-HT receptors was $29.74 \% \pm 1.6$, which was even slightly higher than two rab5's expressed together $(25.58 \% \pm 4.6)$. Here, a strong FRET signal is expected as the proteins localize to the same organelles and are therefore in close proximity. Testing unspecific interaction by co-expressing 5-ht 5 b with rab5 showed a significantly lower $\mathrm{F}_{\mathrm{app}}$ of $9.56 \% \pm 1.1$. Here, some FRET might be expected, as $5-\mathrm{ht}_{5 \mathrm{~b}}$ co-localizes with endosomes (Figure 1C), but the FRET signal was significantly smaller compared to the $5-\mathrm{HT}_{1 \mathrm{~A}}: 5-\mathrm{ht}_{5 \mathrm{~b}}$ signal. The protein pair of $5-\mathrm{ht}_{5 \mathrm{~b}}$ and Lampl produced a very low $\mathrm{F}_{\text {app }}$ of $0.02 \% \pm 0.7$, as the proteins are on separate organelles (Vogelgesang et al., 2017) and only interact very little.

Then, to quantify the surface expression of $5-\mathrm{HT}_{1 \mathrm{~A}}$ in the absence and in the presence of $5-\mathrm{ht}_{5 \mathrm{~b}}$, we used fluorescence microcopy (Figure 4B). First, we stained only surface-expressed 


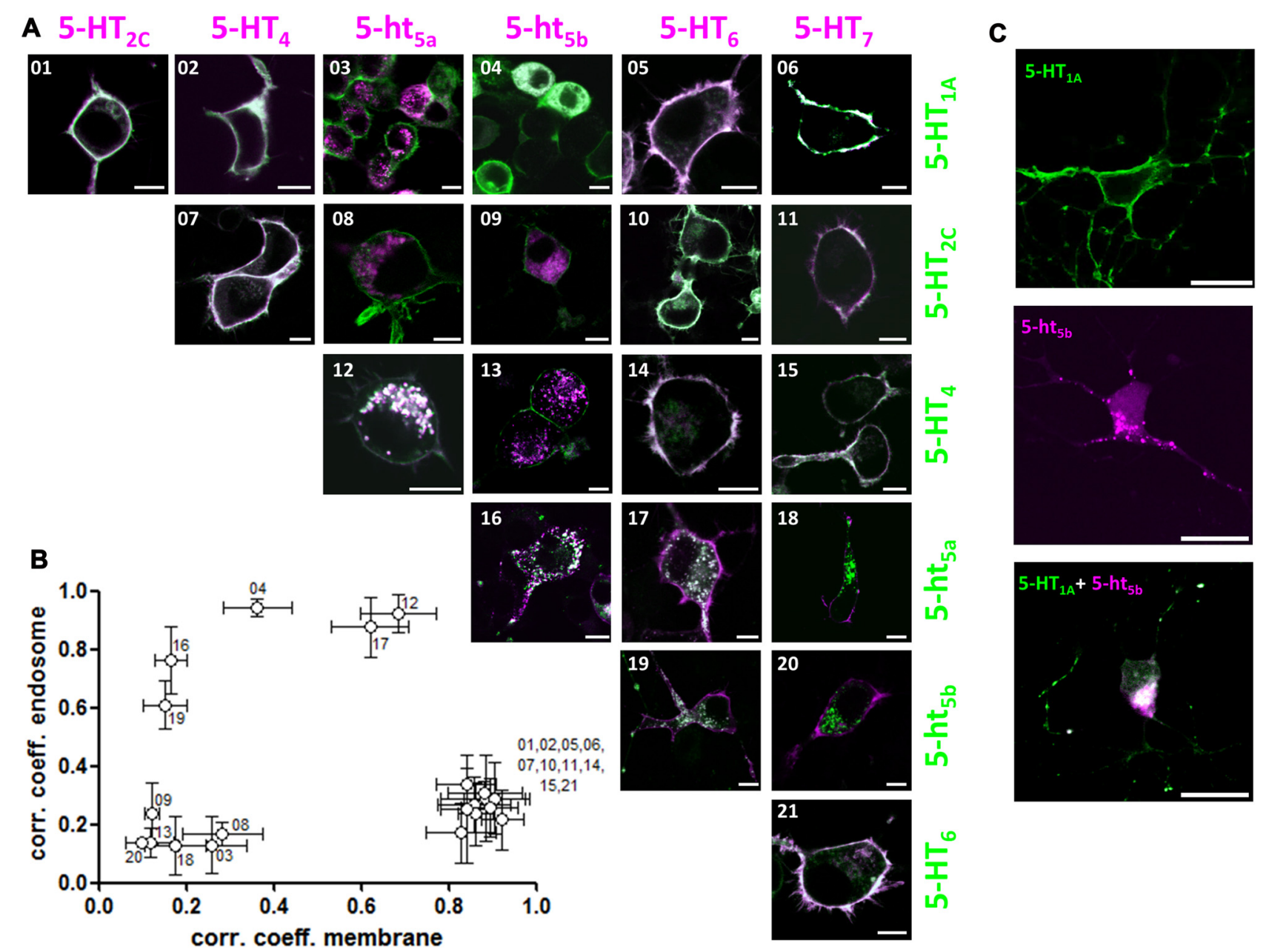

FIGURE 3 | 5-ht 5 b specifically interacts with 5- $\mathrm{HT}_{1 \mathrm{~A}}$ to change the latter's subcellular localization. (A) We transfected a representative member of each 5-HT receptor subgroup tagged with mCherry against the same set of 5-HT receptors tagged with GFP. Each image of the matrix shows $\mathrm{N} 1 \mathrm{E}-115 \mathrm{cells}$ co-expressing two 5 -HT receptors. The images are pseudo-colored purple for the receptor indicated horizontally and pseudo-colored green for the receptor indicated vertically. Co-localization is shown in yellow. 5-ht 5 b specifically interacts with $5-\mathrm{HT}_{1 \mathrm{~A}}(\mathrm{O} 4)$ with the normally strictly membrane-bound 5 - $\mathrm{HT}_{1 \mathrm{~A}}$ receptors partly retained

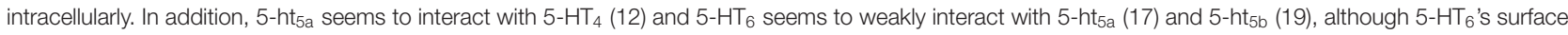
expression remains strong. No other $5-\mathrm{HT}$ receptors seem to interact with each other in a way that changes subcellular localization. Scale bars in all images are $10 \mu \mathrm{m}$. (B) For quantification, we separately calculated Pearson's correlation coefficients for the fluorescence signals at the membrane and at intracellular organelles by manually applying regions of interest (ROI). Plotting the organelle correlation coefficient over the membrane correlation coefficient for each receptor pair resulted in three populations of receptors. One population displays a high correlation at the membrane, but not at intracellular organelles. The second population displays correlation in neither compartment while the third population displays high correlation at intracellular compartments. (C) To verify interaction of 5 - $\mathrm{HT}_{1 \mathrm{~A}}$ and 5 -ht $5 \mathrm{~b}$, we transfected primary hippocampal neurons with expression constructs of both receptors. 5-HT 1 (green) localizes to the cell membrane, while 5-ht bb $_{\text {( }}$ (purple) localizes to intracellular organelles, while co-expression of both receptors shows intracellular co-localization with no discernable membrane staining by 5 - $\mathrm{HT}$ 1A. Scale bars in all images are $20 \mu \mathrm{m}$

$5-\mathrm{HT}_{1 \mathrm{~A}}$ (green) in live cells, as antibodies cannot penetrate through the membrane. Then we fixed and permeabilized the cells and stained $5-\mathrm{HT}_{1 \mathrm{~A}}$ again with different primary and secondary antibodies, this time staining both surface-expressed as well as internal receptors (purple). Cells co-expressing 5 -ht $\mathrm{fb}_{5 \mathrm{~b}}$ were identified by its inherent mCherry-fusion fluorescent signal (red). We quantified the fluorescence intensity of surface-expressed $5-\mathrm{HT}_{1 \mathrm{~A}}$ (green) in cells with and without $5-\mathrm{ht}_{5 \mathrm{~b}}$ signal and found a reduction of $5-\mathrm{HT}_{1 \mathrm{~A}}$ surface expression by $52.3 \% \pm 8.05$ in cells co-expressing $5-\mathrm{ht}_{5 \mathrm{~b}}$.
To quantify $5-\mathrm{HT}_{1 \mathrm{~A}}$ in a larger amount of cells, we used FACS (Figure 4C). Cells expressing $5-\mathrm{HT}_{1 \mathrm{~A}}$ together with an equal amount of filler DNA was used to determine $5-\mathrm{HT}_{1 \mathrm{~A}}$ surface expression under control conditions. Co-expression of $5-\mathrm{HT}_{1 \mathrm{~A}}$ with an equal amount of $5-\mathrm{ht}_{5 \mathrm{a}}$ did not change the degree of surface expression. This indicates that the mere presence of another plasmid or receptor did not affect the membrane localization of $5-\mathrm{HT}_{1 \mathrm{~A}}$. However, the surface expression of $5-\mathrm{HT}_{1 \mathrm{~A}}$ was reduced by $48.8 \% \pm 17.4 \%$ when it was expressed with an equal amount of $5-\mathrm{ht}_{5 \mathrm{~b}}$ (Figure $4 \mathrm{C}$ ). The reduction of surface-expressed $5-\mathrm{HT}_{1 \mathrm{~A}}$ was 

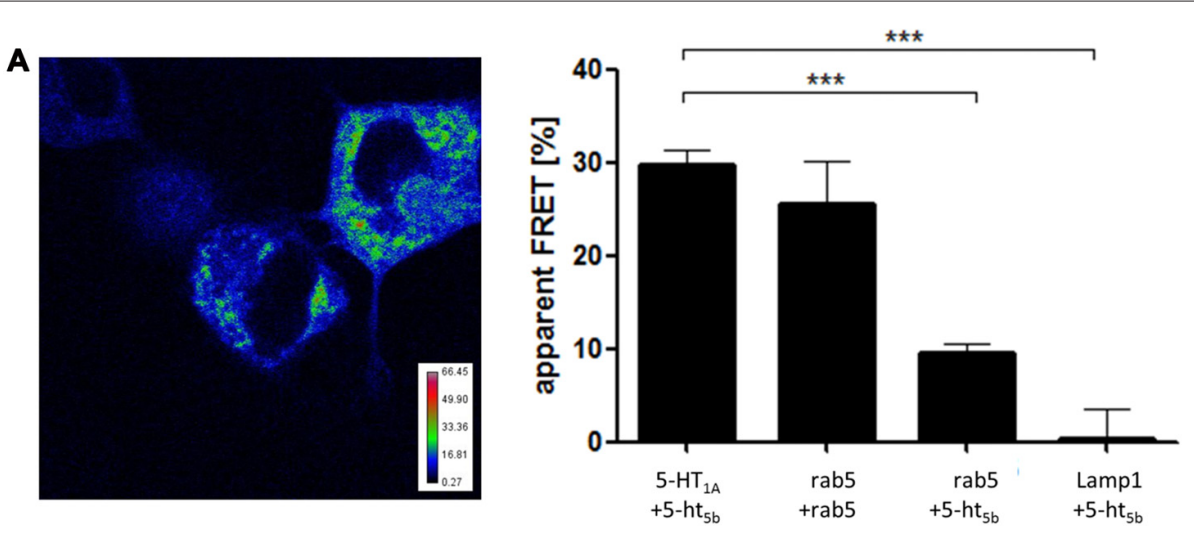

B 1. stain surface-expressed $5-\mathrm{HT}_{1 \mathrm{~A}}$ in life cells
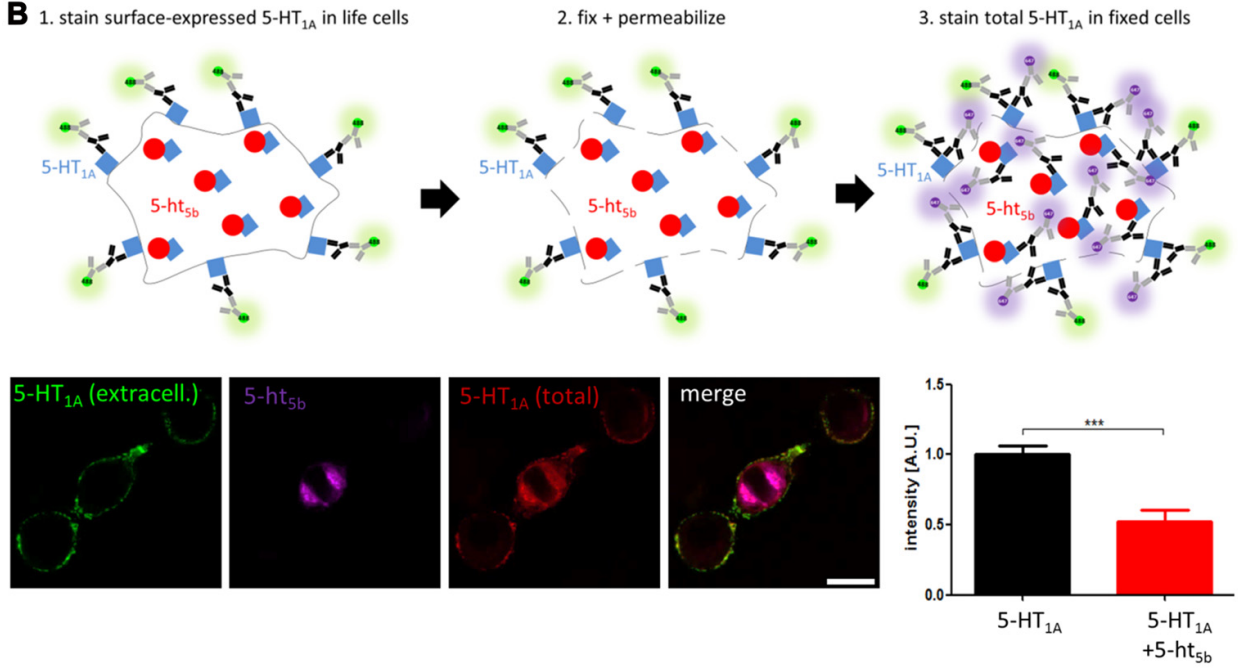

C
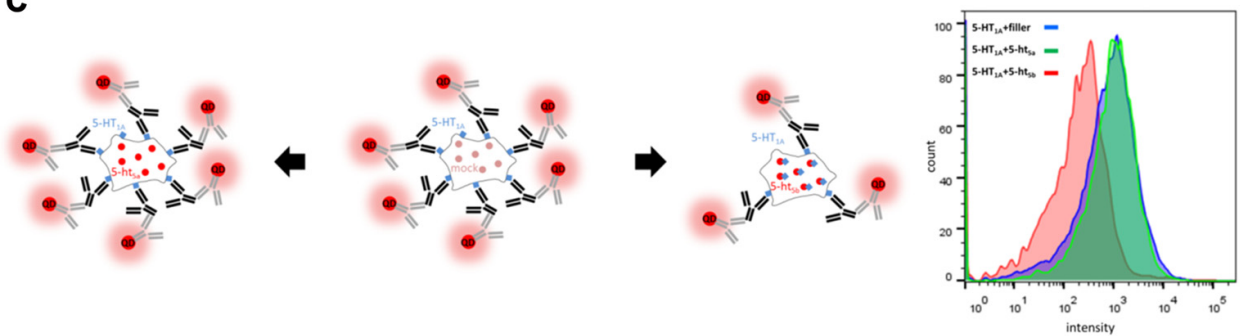

FIGURE 4 | Analysis of receptor interaction. (A) Acceptor-photobleaching Förster Resonance Energy Transfer (abFRET) microscopy was used to determine the extent of protein:protein-interaction. Protein pairs of 5- $\mathrm{HT}_{1 \mathrm{~A}}: 5-\mathrm{ht}_{5 \mathrm{~b}}$, rab5:rab5, 5-ht $\mathrm{fb}_{\mathrm{b}}$ :rab5 and 5-ht $5 \mathrm{~b}$ :Lamp1 were co-expressed in N1E-115 cells at equimolar concentrations and the apparent FRET efficiency $\left(\mathrm{F}_{\mathrm{app}}\right)$ was measured. The color-coded image shows an exemplary experiment of 5-HT $\mathrm{T}_{1 \mathrm{~A}}: 5$-ht $\mathrm{h}_{5 \mathrm{~b}}$, while the bar

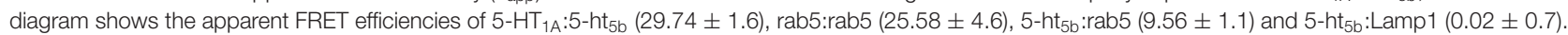
Asterisks indicate significance ${ }^{* * *} p \leq 0.001$; one-way-ANOVA with Bonferroni's post-test for multiple comparisons). (B) Immunohistochemical analysis of distribution and equal expression levels. Non-permeabilized cells were stained for $5-\mathrm{HT}_{1 \mathrm{~A}}$ (green), then fixed and permeabilized and stained again for 5 - $\mathrm{HT} \mathrm{T}_{1 \mathrm{~A}}$ (purple). 5 -ht $\mathrm{f}_{5 \mathrm{~b}}$ is co-expressed in some cells as a fusion protein with a fluorescent tag (red). The fluorescence intensity of the first 5 - $\mathrm{HT}_{1 \mathrm{~A}}$ staining was then measured in cells expressing $5-\mathrm{HT}_{1 \mathrm{~A}}$ and in cells expressing $5-\mathrm{HT}_{1 \mathrm{~A}}$ and $5-\mathrm{ht} \mathrm{t}_{5 \mathrm{~b}}$. The cartoon shows the experimental procedure. The bar diagram shows the mean fluorescence intensities of $5-\mathrm{HT}_{1 \mathrm{~A}}$ reactivity in cells expressing only $5-\mathrm{HT}_{1 \mathrm{~A}}$ and in cells expressing $5-\mathrm{HT}_{1 \mathrm{~A}}(1.0 \pm 0.06)$ and 5 -ht $\mathrm{t}_{5 \mathrm{~b}}(0.52 \pm 0.08)(* * * p \leq 0.001$; unpaired $t$-test). (C) The effect of $5-\mathrm{HT}_{1 \mathrm{~A}}: 5-\mathrm{ht}_{5 \mathrm{~b}}$ co-expression on $5-\mathrm{HT}_{1 \mathrm{~A}}$ surface localization was quantified by fluorescence activated cell sorting (FACS) analysis of N1E-115 cells expressing $\mathrm{HA}-5-\mathrm{HT}_{1 \mathrm{~A}}$ alone or together with $5-\mathrm{ht} \mathrm{f}_{5 \mathrm{~b}}$. Expressing $5-\mathrm{HT}_{1 \mathrm{~A}}$ together with an equal amount of filler DNA was used to determine 5- $\mathrm{HT}$ 1A surface expression under control conditions (blue). Co-expression of 5- $\mathrm{HT}_{1 \mathrm{~A}}$ with an equal amount of non-interacting 5-ht 5 a did not change the degree of surface expression (green). Co-expression of 5- $\mathrm{HT}_{1 \mathrm{~A}}$ with an equal amount of $5-\mathrm{ht}_{5 \mathrm{~b}}$ decreased the cell surface expression of $5-\mathrm{HT}_{1 \mathrm{~A}}$ by $48.8 \% \pm 17.4 \%$. The cartoon shows the experimental procedure. Labeling was directed at $\mathrm{HA}$-tag on $5-\mathrm{HT}_{1 \mathrm{~A}}$ with quantum dot-coupled secondary antibodies. To avoid skewing results by transcription level effects in the control measurement, an unspecific filler plasmid (mock) was co-transfected in place of the second receptor to maintain the same total amount of transfected plasmid. 


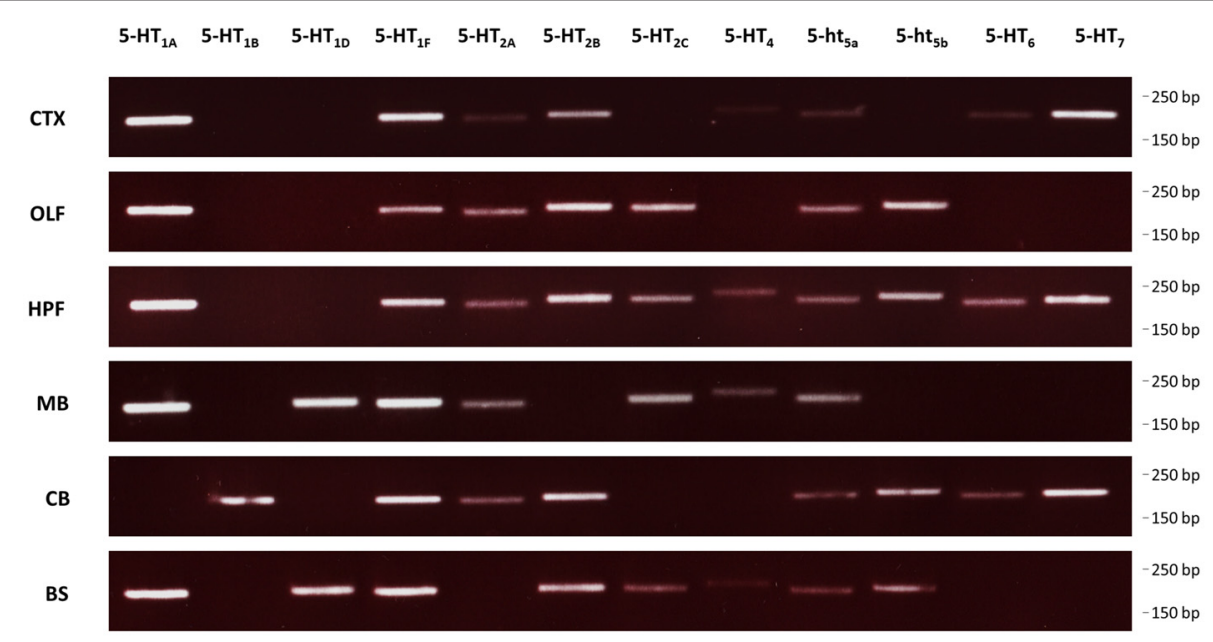

FIGURE 5 | Expression of 5-HT receptors in the mouse brain. RT-PCR was used to detect expression of all 5-HT receptors in select brain regions of mice. CTX, cortex; OLF, bulbus olfactorius; HFP, hippocampal formation; MB, midbrain; CB, cerebellum; BS, brainstem.

consistent with the reduction seen with immunohistochemistry (Figure 4B).

While the translocation of $5-\mathrm{HT}_{1 \mathrm{~A}}$ to a different sub-cellular localization was obvious (Figure 3A04), the amount of surface availability could also be affected by different expression levels caused through co-transfection. As expression of all receptor constructs is CMV driven and all construct have roughly the same size, we regard this as unlikely. Nevertheless, we analyzed whether expression levels of $5-\mathrm{HT}_{1 \mathrm{~A}}$ were affected by co-transfection by comparing the fluorescence intensity of 5 - $\mathrm{HT}_{1 \mathrm{~A}}$-GFP in cells expressing equal amounts of $5-\mathrm{HT}_{1 \mathrm{~A}}$ and a filler DNA or cells expressing $5-\mathrm{HT}_{1 \mathrm{~A}}$ and $5-\mathrm{ht}_{5 \mathrm{~b}}$. Although expression levels of both receptors fluctuated in individual cells, we found no significant overall differences (Supplementary Figure S1) that could explain the 2 -fold reduction in surface expression seen above.

With direct interaction being the most likely mechanism, we cannot rule out indirect interaction. It has been shown previously that transport of $5-\mathrm{HT}_{1 \mathrm{~A}}$ in neurons is controlled by co-factor Yif1b (Carrel et al., 2008), but the involvement of adaptor proteins will be the topic of further studies.

While the change in subcellular localization was most pronounced for $5-\mathrm{HT}_{1 \mathrm{~A}}$ by $5-\mathrm{ht}_{5 \mathrm{~b}}$, for completeness we would like to mention additional possible interactions that were revealed by plotting the correlation coefficients (Figure 3B). We found that $5-\mathrm{ht}_{5 \mathrm{a}}$ co-localized with $5-\mathrm{HT}_{4}$ (Figure 3A12) and that both $5-\mathrm{ht}_{5}$ receptors showed moderate co-localization with $5-\mathrm{HT}_{6}$ (Figures $3 \mathrm{A17}$ and 3A19). Although intracellular aggregation became more pronounced upon co-expression, both $5-\mathrm{HT}_{4}$ and $5-\mathrm{HT}_{6}$ showed already minor intracellular clusters when expressed alone (Figure 1A). In these cases, overloaded trafficking is a more likely mechanism, but analysis is more complicated and will be done at a later time.

\section{Co-Expression of Serotonin Receptors in the Mouse Brain}

We used RT-PCR to determine the expression of all receptors in different regions of the brain (Figure 5). RT-PCR confirmed wide-spread 5-HT receptor expression in the murine brain with multiple receptors being expressed in basically every region analyzed. Among these, the hippocampal formation showed the largest diversity of all regions analyzed. Specifically, for $5-\mathrm{HT}_{1 \mathrm{~A}}$ and $5-h t_{5 b}$, we found regional co-expression in the bulbus olfactorius, the hippocampal formation and the brainstem.

\section{Identification of Interaction Domains}

Having prepared some hybrid receptors for the study of glycosylation and trafficking, we continued this strategy to try and define domains which would explain the specific interaction between 5- $\mathrm{HT}_{1 \mathrm{~A}}$ and 5-ht $5 \mathrm{~b}$ (Figure 6A).

Replacing the PDZ-like C-terminal domain of 5-ht 5 b with that of $5-\mathrm{HT}_{1 \mathrm{~A}}$ had no influence on subcellular localization or interaction (HRV-15, Figure 6B).

A hybrid receptor (HRV-17) consisting of $5-\mathrm{HT}_{1 \mathrm{~A}}$ (from start up to TMD V) and 5-ht 5 b (intracellular loop $3\left(\mathrm{ICL}_{3}\right)$ and onwards) can interact with wild type $5-\mathrm{HT}_{1 \mathrm{~A}}$, although not as strong as seen between both wild-type receptors. This indicated that $\mathrm{ICL}_{3}$ contains at least parts of the interaction domain (Figure 6C).

Exchanging TMD IV and V of 5- $\mathrm{HT}_{1 \mathrm{~A}}$ in the previous hybrid clone by TMD IV and TMD V of $5-\mathrm{ht}_{5 \mathrm{~b}}$, thus creating HRV-18, fully restored the interaction to levels seen for the wild-type receptors (Figure 6D).

\section{Physiological Consequences of 5-ht $5 \mathrm{~b}$ Expression}

The strong and far-ranging expression of 5-ht 5 b (Figure 5) indicates some physiological significance. However, given its intracellular expression, 5-ht $5 \mathrm{~b}$ differs from classical GPCRs. With at best sparse surface expression, $5-\mathrm{ht}_{5 \mathrm{~b}}$ seems to contribute 

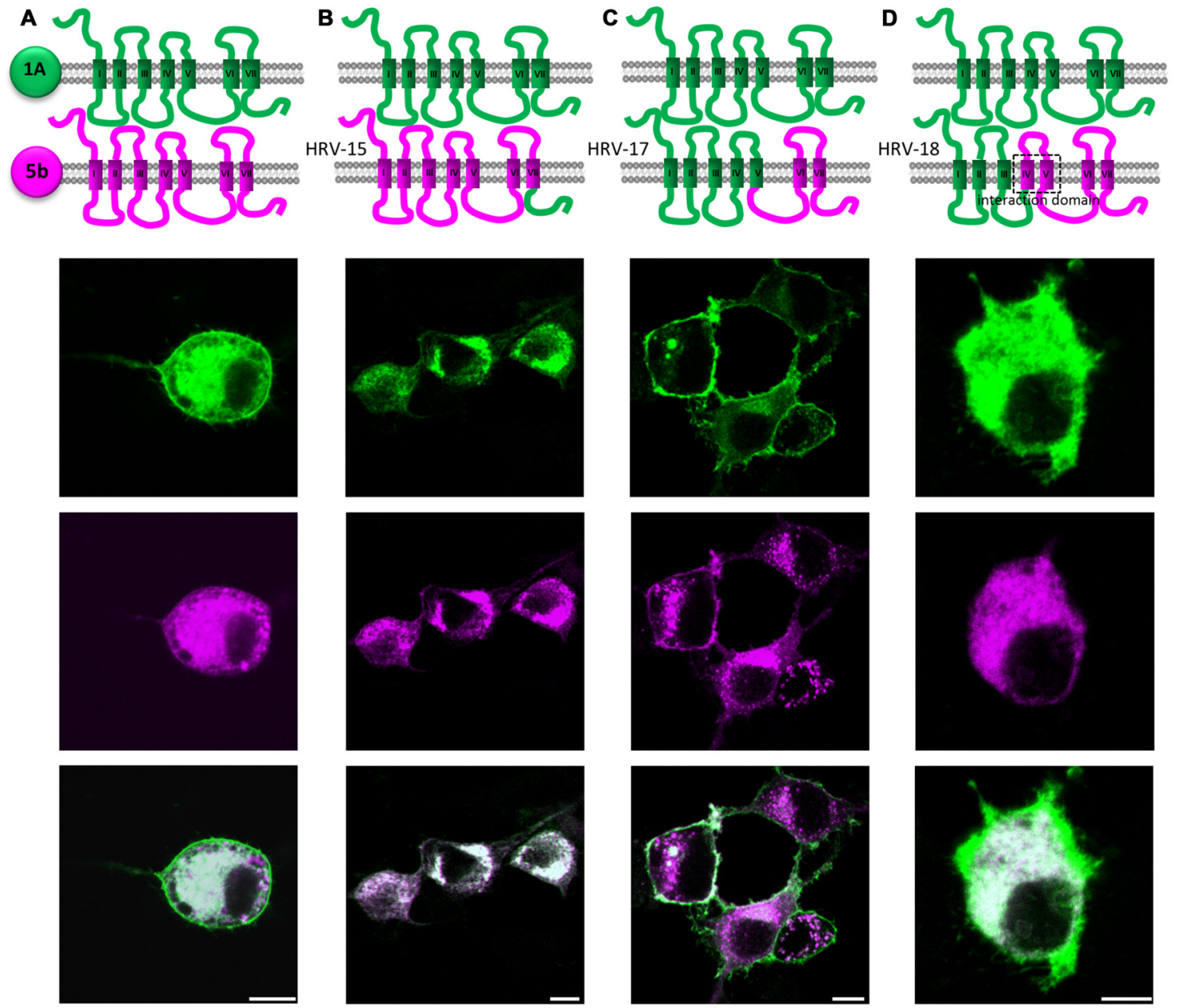

FIGURE 6 | Identification of possible interaction domains between 5-HT 1 A (green) and 5-ht 5 b (purple). N1E-115 cells were transiently transfected with two hybrid receptor variants labeled with eGFP or mCherry. (A) Co-expression of full length 5-HT $1 \mathrm{~A}$ and full length 5-ht $5 \mathrm{~b}$ lead to strong internalization of 5-HT 1 . (B) Replacing the $\mathrm{C}$-terminal domain of 5-ht $\mathrm{b}_{\mathrm{b}}$ with the $\mathrm{C}$-terminal domain of $5-\mathrm{HT}_{1 \mathrm{~A}}(\mathrm{HRV}-15)$ did not change the amount of interaction. (C) Expressing 5 - $\mathrm{HT}_{1 \mathrm{~A}}$ together with a hybrid 5-HT $1 \mathrm{~A}$ where the 3rd intracellular loop and the last two TMDs are from 5-ht $5 \mathrm{~b}(\mathrm{HRV}-17)$, the interaction is greatly reduced or even abolished. (D) Expressing 5- $\mathrm{HT}_{1 \mathrm{~A}}$ together with a hybrid receptor composed of the first three TMDs of 5-HT $1 \mathrm{~A}$ and the last four TMDs of 5-ht $5 \mathrm{~b}$ (HRV-18) show interaction as the two full length receptors.

little to intracellular signaling. However, a more likely function of $5-\mathrm{ht}_{5 \mathrm{~b}}$ could be the modulation of its interaction partner by affecting its surface availability.

The strictly intracellular 5 -ht 5 b did not respond to stimulation by 5 -HT $(-9.46 \% \pm 1.296$, Figure $7 \mathrm{II})$, however, the mere presence of 5 -ht $_{5 \mathrm{~b}}$ decreased the cAMP level, indicating some constitutive activity of $5-\mathrm{ht}_{5 \mathrm{~b}}(-7.75 \% \pm 1.012$, Figure 7I). For $5-\mathrm{HT}_{1 \mathrm{~A}}$ no constitutive activity was measurable $(-2.49 \% \pm 1.366$, Figure 7 III $)$, while application of $5-\mathrm{HT}$ decreased cAMP $(-28.12 \% \pm 1.096$, Figure 7IV). Cells transfected with both receptors showed reduced cAMP levels $(-10.37 \% \pm 1.029$, Figure $7 \mathrm{~V})$. Application of 5 -HT to cells co-expressing both receptors produced a reduction of cAMP $(-19.91 \% \pm 2.219$, Figure $7 \mathrm{VI})$, as activation of $5-\mathrm{HT}_{1 \mathrm{~A}}$ decreased cAMP despite the reduced baseline cAMP level due to 5 -ht $_{5 \mathrm{~b}}$ 's constitutive activity. The reduction of cAMP was smaller compared to cells expressing $5-\mathrm{HT}_{1 \mathrm{~A}}$ alone, yet significant $(p=0.002)$. This clearly showed that co-expression of $5-\mathrm{ht}_{5 \mathrm{~b}} \mathrm{can}$ affect the signaling behavior of other 5 -HT receptors.

\section{DISCUSSION}

In this study we described the behavior of 5-HT receptor 5 -ht ${ }_{5 \mathrm{~b}}$, which manifests in intracellular localization to endosomal compartments and specific interaction with another select member of the 5-HT receptor family.

5 -ht $_{5 \mathrm{~b}}$ localizes to endosomes (Figure 1C), which was also seen for $5-\mathrm{ht}_{5 \mathrm{a}}$ (data not shown) and therefore might present a defining feature of this sub-group of 5 -HT receptors. It might also indicate a physiological significance, as other truncated receptors are retained mainly in the ER (Karpa et al., 2000; Leung et al., 2007; Gonzalez et al., 2011). It is known that many GPCRs 


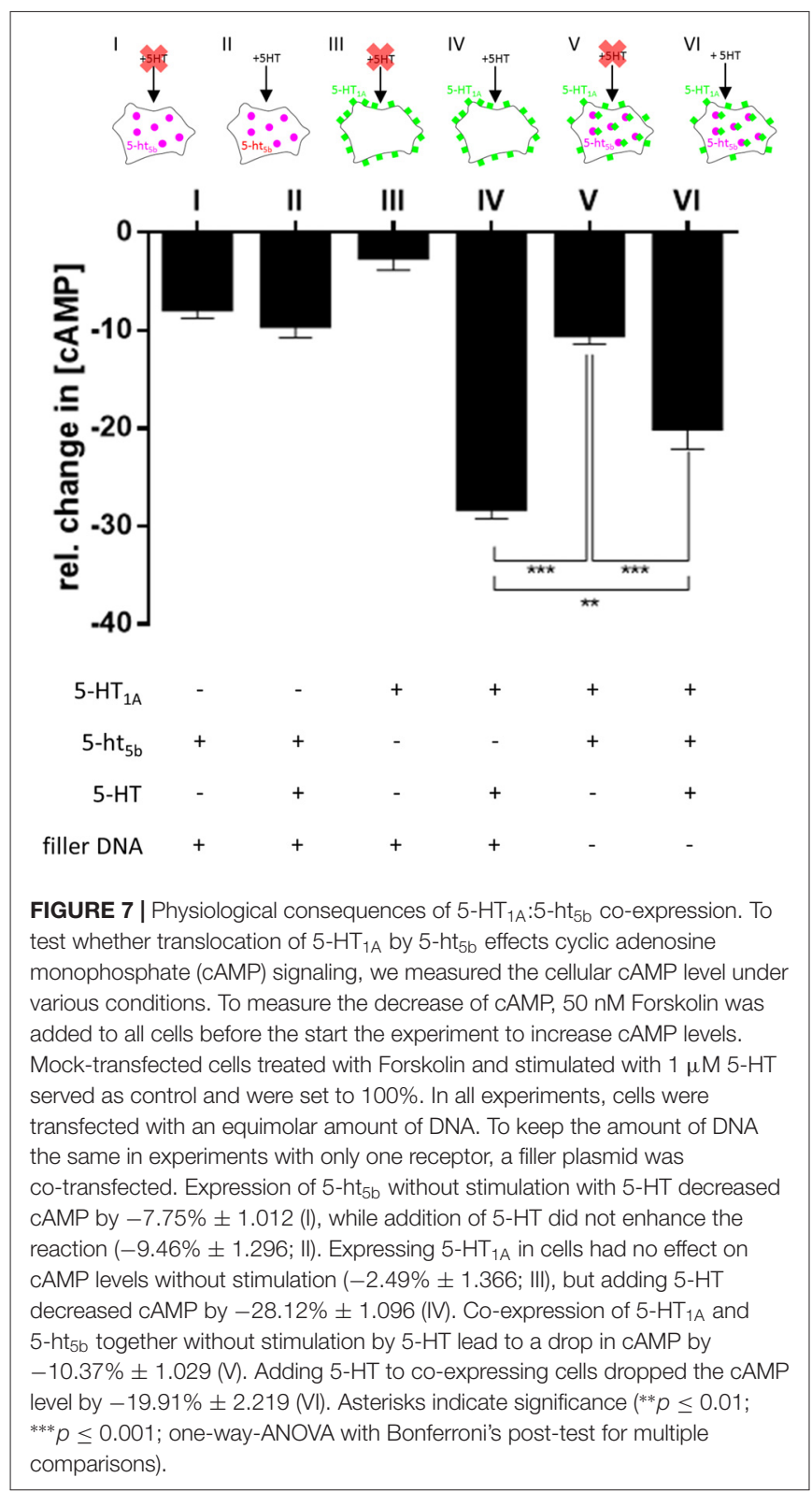

naturally show constitutive activity or that constitutively active mutants exist (Tao, 2008). GPCRs were even described to signal from endosomal vesicles after internalization (Irannejad et al., 2013). Internal signaling might be indicated by the fact that we could measure a minor decrease of cAMP upon expression of 5-ht ${ }_{5 \mathrm{~b}}$ without application of a ligand (Figure 7).

In the literature, several mechanisms, including glycosylation (Dutton et al., 2008), TMD size (Sharpe et al., 2010) or $\mathrm{N}$-terminal signal peptides (Jahnsen and Uhlen, 2012) are discussed to control receptor trafficking to the membrane. The unusual intracellular localization of $5-\mathrm{ht}_{5 \mathrm{a}}$ and $5-\mathrm{ht}_{5 \mathrm{~b}}$ seems to be caused in large part by glycosylation of the $\mathrm{N}$-terminus as artificially increasing the number of glycosylation sites of 5-ht 5 b increases its surface localization (Figures 2H,I). This form of glycosylation was also found to control membrane localization of 5-ht 5 a (Dutton et al., 2008).
Formation of hetero-oligomers has been described for many GPCRs (Schwenk et al., 2010) including 5-HT receptors (Pellissier et al., 2011; Renner et al., 2012), although their interaction is subtle and its physiological significance remains to be shown. Here, $5-\mathrm{ht}_{5 \mathrm{~b}}$ 's affinity to $5-\mathrm{HT}_{1 \mathrm{~A}}$ was so strong that it changes the subcellular localization of $5-\mathrm{HT}_{1 \mathrm{~A}}$. As both 5-HT receptors were found co-expressed in the brain (Figure 5), it is feasible to assume a physiological role for this specific interaction. The interaction mapping is still only rudimentary, but efforts to identify the binding interfaces of class A GPCRs have been ongoing for years, with most studies leaning towards TMD IV and TMD V as dimerization interface (GonzálezMaeso et al., 2008; Johnston et al., 2011; Hu et al., 2012). These were also identified here as a possible location for the interaction interface. With the strong interaction between 5$\mathrm{HT}_{1 \mathrm{~A}}$ and 5-ht $\mathrm{fb}_{5 \mathrm{~b}}$ and an easy read-out through translocation, further studies to fine-map the interaction surface might profit.

The mostly intracellular 5-ht 5 b receptor probably does not relay signals in the conventional way, but by retaining $5-\mathrm{HT}_{1 \mathrm{~A}}$ in intracellular compartments, 5-ht $\mathrm{t}_{5 \mathrm{~b}}$ reduces its surface expression significantly, thus effectively reducing $5-\mathrm{HT}_{1 \mathrm{~A}}$ 's contributions to cellular signaling (Figures 4, 7). In alternate modes of action, 5-ht $t_{5 \mathrm{~b}}$ might modify intracellular signaling by acting on the cAMP level, either through constitutive activity and/or by scavenging G-proteins which would no longer be available for other signal cascades.

It is difficult to define a role for the $5-\mathrm{HT}_{1 \mathrm{~A}}: 5-\mathrm{ht} \mathrm{t}_{5 \mathrm{~b}}$ interaction in RTT, as the syndrome displays very complex genetic imbalances and many different and sometimes opposing therapies seem to improve symptoms in RTT. Within the serotonergic system alone, two previous observations in animal models of RTT might be linked to $5-\mathrm{HT}_{1 \mathrm{~A}}: 5-\mathrm{ht}_{5 \mathrm{~b}}$. Application of $5-\mathrm{HT}_{1 \mathrm{~A}}$ agonists was described to have beneficial effects on the respiratory phenotype in mice (Abdala et al., 2010) and might be linked to the reduction of surface-expressed $5-\mathrm{HT}_{1 \mathrm{~A}}$ by 5 -ht $t_{5 b}$. In contrast, treatment with $5-\mathrm{HT}_{7}$ agonists was reported to improve behavior (De Filippis et al., 2014, 2015a) and might counteract the constitutive down-regulation of cAMP by $5-$ ht $_{5 \mathrm{~b}}$.

However, we would like to advise some caution interpreting these results. Here, we transfected recombinant cDNA at equimolar concentrations into cell lines and measured the effect of receptor activation on cAMP. In vivo, the situation is most likely much more complicated, as receptor expression levels may not be equal, co-factors might be present and signaling cascades are more complex. For example, we did not measure effects on CNG ion channels or on small GTPases. Of interest regarding the physiological function of $5-\mathrm{ht}_{5 \mathrm{~b}}$ is the fact that 5 $\mathrm{HT}_{1 \mathrm{~A}}$ also becomes internalized upon activation, after which it seems to activate the Erk-1/2 signaling pathway (Renner et al., 2012). This is especially interesting as 5 -ht tb $_{\text {b }}$ initially came to our attention when analyzing a mouse model of RTT (Vogelgesang et al., 2017) and modulation of small RhoGTPase activity was shown to have beneficial effects on RTT (De Filippis et al., 2012, 2015b). 


\section{AUTHOR CONTRIBUTIONS}

SN, GJB, SV, TM and MN performed experiments. SN and MN wrote the manuscript.

\section{ACKNOWLEDGMENTS}

This work was supported by the Cluster of Excellence and Deutsche Forschungsgemeinschaft (DFG) Research Center Nanoscale Microscopy and Molecular Physiology of the Brain.

\section{REFERENCES}

Abdala, A. P. L., Dutschmann, M., Bissonnette, J. M., and Paton, J. F. R. (2010). Correction of respiratory disorders in a mouse model of Rett syndrome. Proc. Natl. Acad. Sci. U S A 107, 18208-18213. doi: 10.1073/pnas.1012104107

Azmitia, E. C. (2001). Modern views on an ancient chemical: serotonin effects on cell proliferation, maturation, and apoptosis. Brain Res. Bull. 56, 413-424. doi: 10.1016/s0361-9230(01)00614-1

Bos, J. L. (2006). Epac proteins: multi-purpose cAMP targets. Trends Biochem. Sci. 31, 680-686. doi: 10.1016/j.tibs.2006.10.002

Boyd, G. W., Low, P., Dunlop, J. I., Robertson, L. A., Vardy, A., Lambert, J. J., et al. (2002). Assembly and cell surface expression of homomeric and heteromeric 5-HT3 receptors: the role of oligomerization and chaperone proteins. Mol. Cell. Neurosci. 21, 38-50. doi: 10.1006/mcne.2002.1160

Carrel, D., Masson, J., Al Awabdh, S., Capra, C. B., Lenkei, Z., Hamon, M., et al. (2008). Targeting of the $5-\mathrm{HT}_{1 \mathrm{~A}}$ serotonin receptor to neuronal dendrites is mediated by Yif1B. J. Neurosci. 28, 8063-8073. doi: 10.1523/jneurosci. 4487-07.2008

Choudhury, A., Dominguez, M., Puri, V., Sharma, D. K., Narita, K., Wheatley, C. L., et al. (2002). Rab proteins mediate Golgi transport of caveolainternalized glycosphingolipids and correct lipid trafficking in Niemann-Pick C cells. J. Clin. Invest. 109, 1541-1550. doi: 10.1172/jci200215420

Conklin, B. R., Hsiao, E. C., Claeysen, S., Dumuis, A., Srinivasan, S., Forsayeth, J. R., et al. (2008). Engineering GPCR signaling pathways with RASSLs. Nat. Methods 5, 673-678. doi: 10.1038/nmeth.1232

De Filippis, B., Chiodi, V., Adriani, W., Lacivita, E., Mallozzi, C., Leopoldo, M., et al. (2015a). Long-lasting beneficial effects of central serotonin receptor 7 stimulation in female mice modeling Rett syndrome. Front. Behav. Neurosci. 9:86. doi: 10.3389/fnbeh.2015.00086

De Filippis, B., Valenti, D., Chiodi, V., Ferrante, A., de Bari, L., Fiorentini, C., et al. (2015b). Modulation of Rho GTPases rescues brain mitochondrial dysfunction, cognitive deficits and aberrant synaptic plasticity in female mice modeling Rett syndrome. Eur. Neuropsychopharmacol. 25, 889-901. doi: 10.1016/j.euroneuro. 2015.03.012

De Filippis, B., Fabbri, A., Simone, D., Canese, R., Ricceri, L., MalchiodiAlbedi, F., et al. (2012). Modulation of RhoGTPases improves the behavioral phenotype and reverses astrocytic deficits in a mouse model of Rett syndrome. Neuropsychopharmacology 37, 1152-1163. doi: 10.1038/npp. 2011.301

De Filippis, B., Nativio, P., Fabbri, A., Ricceri, L., Adriani, W., Lacivita, E., et al. (2014). Pharmacological stimulation of the brain serotonin receptor 7 as a novel therapeutic approach for Rett syndrome. Neuropsychopharmacology 39, 2506-2518. doi: 10.1038/npp.2014.105

Delépine, C., Nectoux, J., Letourneur, F., Baud, V., Chelly, J., Billuart, P., et al. (2015). Astrocyte transcriptome from the Mecp2308-Truncated mouse model of rett syndrome. Neuromolecular Med. 17, 353-363. doi: 10.1007/s12017-0158363-9

Dutton, A. C., Massoura, A. N., Dover, T. J., Andrews, N. A., and Barnes, N. M. (2008). Identification and functional significance of $N$-glycosylation of the 5-ht $5 \mathrm{~A}$ receptor. Neurochem. Int. 52, 419-425. doi: 10.1016/j.neuint. 2007.07.020

Gonzalez, A., Borquez, M., Trigo, C. A., Brenet, M., Sarmiento, J. M., Figueroa, C. D., et al. (2011). The splice variant of the V2 vasopressin
We acknowledge support by the Open Access Publication Funds of the Göttingen University. We would like to thank Christina Schäfer for the preparation of primary hippocampal neurons and Prof. Swen Hülsmann for helpful discussions.

\section{SUPPLEMENTARY MATERIAL}

The Supplementary Material for this article can be found online at: http://journal.frontiersin.org/article/10.3389/fnmol.2017.002 99/full\#supplementary-material receptor adopts alternative topologies. Biochemistry 50, 4981-4986. doi: 10.1021/bi2001278

González-Maeso, J., Ang, R., Yuen, T., Chan, P., Weisstaub, N. V., LopezGimenez, J. F., et al. (2008). Identification of a serotonin/glutamate receptor complex implicated in psychosis. Nature 452, 93-97. doi: 10.1038/nature06612

Grailhe, R., Grabtree, G. W., and Hen, R. (2001). Human 5-HT 5 receptors: the $5-\mathrm{HT}_{5 \mathrm{~A}}$ receptor is functional but the $5-\mathrm{HT}_{5 \mathrm{~B}}$ receptor was lost during mammalian evolution. Eur. J. Pharmacol. 418, 157-167. doi: 10.1016/s00142999(01)00933-5

Guangyu, W. U. (Ed.). (2015). Trafficking of GPCRs: 132 (Progress in molecular biology and translational science). Available online at: http://www amazon.de/Trafficking-GPCRs-Progress-Molecular-Translational-ebook/dp/ B00ZI3BLC0

Gurevich, V. V., and Gurevich, E. V. (2008). GPCR monomers and oligomers: it takes all kinds. Trends Neurosci. 31, 74-81. doi: 10.1016/j.tins.2007.11.007

Guy, J., Hendrich, B., Holmes, M., Martin, J. E., and Bird, A. (2001). A mouse Mecp2-null mutation causes neurological symptoms that mimic Rett syndrome. Nat. Genet. 27, 322-326. doi: 10.1038/85899

Hoyer, D., Hannon, J. P., and Martin, G. R. (2002). Molecular, pharmacological and functional diversity of 5-HT receptors. Pharmacol. Biochem. Behav. 71, 533-554. doi: 10.1016/s0091-3057(01)00746-8

Hu, J., Thor, D., Zhou, Y., Liu, T., Wang, Y., McMillin, S. M., et al. (2012). Structural aspects of $\mathrm{M}_{3}$ muscarinic acetylcholine receptor dimer formation and activation. FASEB J. 26, 604-616. doi: 10.1096/fj.11-191510

Irannejad, R., Tomshine, J. C., Tomshine, J. R., Chevalier, M., Mahoney, J. P., Steyaert, J., et al. (2013). Conformational biosensors reveal GPCR signalling from endosomes. Nature 495, 534-538. doi: 10.1038/nature 12000

Jahnsen, J. A., and Uhlen, S. (2012). The N-terminal region of the human 5- $\mathrm{HT}_{2} \mathrm{C}$ receptor has as a cleavable signal peptide. Eur. J. Pharmacol. 684, 44-50. doi: 10.1016/j.ejphar.2012.03.043

Johnston, J. M., Aburi, M., Provasi, D., Bortolato, A., Urizar, E., Lambert, N. A., et al. (2011). Making structural sense of dimerization interfaces of delta opioid receptor homodimers. Biochemistry 50, 1682-1690. doi: 10.1021/bi101474v

Karpa, K. D., Lin, R., Kabbani, N., and Levenson, R. (2000). The dopamine D3 receptor interacts with itself and the truncated D3 splice variant d3nf: D3-D3nf interaction causes mislocalization of D3 receptors. Mol. Pharmacol. 58, 677-683. doi: 10.1124/mol.58.4.677

Kaupp, U. B., and Seifert, R. (2002). Cyclic nucleotide-gated ion channels. Physiol. Rev. 82, 769-824. doi: 10.1152/physrev.00008.2002

Krogh, A., Larsson, B., von Heijne, G., and Sonnhammer, E. L. (2001). Predicting transmembrane protein topology with a hidden Markov model: application to complete genomes. J. Mol. Biol. 305, 567-580. doi: 10.1006/jmbi.2000.4315

Leung, P.-K., Chow, K. B. S., Lau, P.-N., Chu, K.-M., Chan, C.-B., Cheng, C. H. K., et al. (2007). The truncated ghrelin receptor polypeptide (GHS-R1b) acts as a dominant-negative mutant of the ghrelin receptor. Cell. Signal. 19, 1011-1022. doi: 10.1016/j.cellsig.2006.11.011

Maekawa, T., Kim, S., Nakai, D., Makino, C., Takagi, T., Ogura, H., et al. (2010). Social isolation stress induces ATF-7 phosphorylation and impairs silencing of the 5-HT 5B receptor gene. EMBO J. 29, 196-208. doi: 10.1038/emboj.2009.318

Matsuda, M., Imaoka, T., Vomachka, A. J., Gudelsky, G. A., Hou, Z., Mistry, M., et al. (2004). Serotonin regulates mammary gland development via an autocrine-paracrine loop. Dev. Cell 6, 193-203. doi: 10.1016/s15345807(04)00022-x 
Matthes, H., Boschert, U., Amlaiky, N., Grailhe, R., Plassat, J. L., Muscatelli, F., et al. (1993). Mouse 5-hydroxytryptamine5A and 5-hydroxytryptamine5B receptors define a new family of serotonin receptors: cloning, functional expression, and chromosomal localization. Mol. Pharmacol. 43, 313-319.

Meinkoth, J. L., Alberts, A. S., Went, W., Fantozzi, D., Taylor, S. S., Hagiwara, M., et al. (1993). Signal transduction through the cAMP-dependent protein kinase. Mol. Cell. Biochem. 127-128, 179-186. doi: 10.1007/978-1-4615-2600-1_17

Nelson, D. L. (2004). 5-HT5 receptors. Curr. Drug Targets CNS Neurol. Disord. 3 , 53-58. doi: 10.2174/1568007043482606

Niebert, M., Vogelgesang, S., Koch, U. R., Bischoff, A.-M., Kron, M., Bock, N., et al. (2011). Expression and function of serotonin 2A and $2 \mathrm{~B}$ receptors in the mammalian respiratory network. PLoS One 6:e21395. doi: 10.1371/journal. pone.0021395

Pellissier, L. P., Barthet, G., Gaven, F., Cassier, E., Trinquet, E., Pin, J. P., et al. (2011). G protein activation by serotonin type 4 receptor dimers: evidence that turning on two protomers is more efficient. J. Biol. Chem. 286, 9985-9997. doi: 10.1074/jbc.M110.201939

Plassat, J. L., Boschert, U., Amlaiky, N., and Hen, R. (1992). The mouse 5 HT5 receptor reveals a remarkable heterogeneity within the 5HT1D receptor family. EMBO J. 11, 4779-4786.

Rees, S., den Daas, I., Foord, S., Goodson, S., Bull, D., Kilpatrick, G., et al. (1994). Cloning and characterisation of the human $5-\mathrm{HT}_{5 \mathrm{~A}}$ serotonin receptor. FEBS Lett. 355, 242-246. doi: 10.1016/0014-5793(94)01209-1

Renner, U., Zeug, A., Woehler, A., Niebert, M., Dityatev, A., Dityateva, G., et al. (2012). Heterodimerization of serotonin receptors $5-\mathrm{HT}_{1 \mathrm{~A}}$ and $5-\mathrm{HT}_{7}$ differentially regulates receptor signalling and trafficking. J. Cell Sci. 125, 2486-2499. doi: 10.1242/jcs.101337

Revelo, N. H., Kamin, D., Truckenbrodt, S., Wong, A. W., Reuter-Jessen, K., Reisinger, E., et al. (2014). A new probe for super-resolution imaging of membranes elucidates trafficking pathways. J. Cell Biol. 205, 591-606. doi: $10.1083 /$ jcb.201402066

Schneider, C. A., Rasband, W. S., and Eliceiri, K. W. (2012). NIH Image to ImageJ: 25 years of image analysis. Nat. Methods 9, 671-675. doi: 10.1038/nmeth.2089

Schwenk, J., Metz, M., Zolles, G., Turecek, R., Fritzius, T., Bildl, W., et al. (2010). Native $G_{A B A}$ receptors are heteromultimers with a family of auxiliary subunits. Nature 465, 231-235. doi: 10.1038/nature08964

Sharpe, H. J., Stevens, T. J., and Munro, S. (2010). A comprehensive comparison of transmembrane domains reveals organelle-specific properties. Cell 142, 158-169. doi: 10.1016/j.cell.2010.05.037
Simrick, S., Schindler, R. F., Poon, K.-L., and Brand, T. (2013). Popeye domain-containing proteins and stress-mediated modulation of cardiac pacemaking. Trends Cardiovasc. Med. 23, 257-263. doi: 10.1016/j.tcm.2013. 02.002

Slominski, A., Wortsman, J., and Tobin, D. J. (2005). The cutaneous serotoninergic/melatoninergic system: securing a place under the sun. FASEB J. 19, 176-194. doi: 10.1096/fj.04-2079rev

Tao, Y.-X. (2008). Constitutive activation of G protein-coupled receptors and diseases: insights into mechanisms of activation and therapeutics. Pharmacol. Ther. 120, 129-148. doi: 10.1016/j.pharmthera.2008.07.005

Uetz, P., Abdelatty, F., Villarroel, A., Rappold, G., Weiss, B., and Koenen, M. (1994). Organisation of the murine 5-HT3 receptor gene and assignment to human chromosome 11. FEBS Lett. 339, 302-306. doi: 10.1016/00145793(94)80435-4

Vagin, O., Kraut, J. A., and Sachs, G. (2009). Role of N-glycosylation in trafficking of apical membrane proteins in epithelia. Am. J. Physiol. Renal Physiol. 296, F459-F469. doi: 10.1152/ajprenal.90340.2008

van Royen, M. E., Dinant, C., Farla, P., Trapman, J., and Houtsmuller, A. B. (2009). FRAP and FRET methods to study nuclear receptors in living cells. Methods Mol. Biol. 505, 69-96. doi: 10.1007/978-1-60327-575-0_5

Vogelgesang, S., Niebert, S., Renner, U., Möbius, W., Hülsmann, S., Manzke, T., et al. (2017). Analysis of the serotonergic system in a mouse model of rett syndrome reveals unusual upregulation of serotonin receptor 5b. Front. Mol. Neurosci. 10:61. doi: 10.3389/fnmol.2017.00061

Vonderheit, A., and Helenius, A. (2005). Rab7 associates with early endosomes to mediate sorting and transport of Semliki forest virus to late endosomes. PLoS Biol. 3:e233. doi: 10.1371/journal.pbio.0030233

Conflict of Interest Statement: The authors declare that the research was conducted in the absence of any commercial or financial relationships that could be construed as a potential conflict of interest.

Copyright (c) 2017 Niebert, van Belle, Vogelgesang, Manzke and Niebert. This is an open-access article distributed under the terms of the Creative Commons Attribution License (CC BY). The use, distribution or reproduction in other forums is permitted, provided the original author(s) or licensor are credited and that the original publication in this journal is cited, in accordance with accepted academic practice. No use, distribution or reproduction is permitted which does not comply with these terms. 